\title{
A new estimation of the recent tropospheric molecular hydrogen budget using atmospheric observations and variational inversion
}

C. E. Yver ${ }^{1}$, I. C. Pison ${ }^{1,2}$, A. Fortems-Cheiney ${ }^{1}$, M. Schmidt ${ }^{1}$, F. Chevallier ${ }^{1}$, M. Ramonet ${ }^{1}$, A. Jordan ${ }^{3}$, O. A. Søvde ${ }^{4}$,

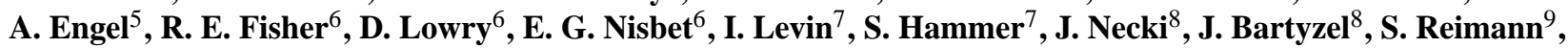
M. K. Vollmer ${ }^{9}$, M. Steinbacher ${ }^{9}$, T. Aalto ${ }^{10}$, M. Maione ${ }^{11}$, J. Arduini ${ }^{11}$, S. O'Doherty ${ }^{12}$, A. Grant ${ }^{12}$, W. T. Sturges ${ }^{13}$,

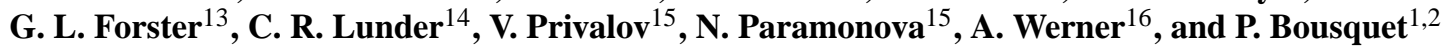

${ }^{1}$ Laboratoire des Sciences du Climat et de l'Environnement (LSCE), Gif-sur-Yvette, France

${ }^{2}$ Université de Versailles Saint-Quentin-en-Yvelines (UVSQ), Versailles, France

${ }^{3}$ Max-Planck Institut für Biogeochemie, Jena, Germany

${ }^{4}$ University of Oslo, Oslo, Norway

${ }^{5}$ Institut für Meteorologie und Geophysik, Goethe-Universität Frankfurt, Frankfurt, Germany

${ }^{6}$ Department of Earth Sciences, Royal Holloway, University of London, Egham, UK

${ }^{7}$ Institut für Umweltphysik, Heidelberg Universität, Heidelberg, Germany

${ }^{8}$ Faculty of Physics and Applied Computer Science, AGH-University of Science and Technology, Krakow, Poland

${ }^{9}$ Empa, Swiss Federal Institute for Materials Science and Technology, Laboratory for Air Pollution/Environmental

Technology, Duebendorf, Switzerland

${ }^{10}$ Finnish Meteorological Institute, Climate Change Research, Helsinki, Finland

${ }^{11}$ Universitá degli Studi di Urbino, DiSBeF, Sezione di Scienze Chimiche, Urbino, Italy

${ }^{12}$ School of Chemistry, University of Bristol, UK

${ }^{13}$ School of Environmental Sciences, University of East Anglia, Norwich, UK

${ }^{14}$ Norsk Institutt for Luftforskning, Kjeller, Norway

${ }^{15}$ Voeikov Main Geophysical Observatory, St. Petersburg, Russia

${ }^{16}$ Deutscher Wetterdienst, Meteorologisches Observatorium, Hohenpeissenberg, Germany

Received: 18 October 2010 - Published in Atmos. Chem. Phys. Discuss.: 25 November 2010

Revised: 25 February 2011 - Accepted: 2 April 2011 - Published: 11 April 2011

\begin{abstract}
This paper presents an analysis of the recent tropospheric molecular hydrogen $\left(\mathrm{H}_{2}\right)$ budget with a particular focus on soil uptake and European surface emissions. A variational inversion scheme is combined with observations from the RAMCES and EUROHYDROS atmospheric networks, which include continuous measurements performed between mid-2006 and mid-2009. Net $\mathrm{H}_{2}$ surface flux, then deposition velocity and surface emissions and finally, deposition velocity, biomass burning, anthropogenic and $\mathrm{N}_{2}$ fixationrelated emissions were simultaneously inverted in several scenarios. These scenarios have focused on the sensibility of the soil uptake value to different spatio-temporal distributions. The range of variations of these diverse inversion sets
\end{abstract}

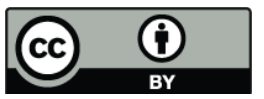

Correspondence to: C. E. Yver (camille.yver@lsce.ipsl.fr) generate an estimate of the uncertainty for each term of the $\mathrm{H}_{2}$ budget. The net $\mathrm{H}_{2}$ flux per region (High Northern Hemisphere, Tropics and High Southern Hemisphere) varies between -8 and $+8 \mathrm{Tg} \mathrm{yr}^{-1}$. The best inversion in terms of fit to the observations combines updated prior surface emissions and a soil deposition velocity map that is based on bottomup and top-down estimations. Our estimate of global $\mathrm{H}_{2}$ soil uptake is $-59 \pm 9 \mathrm{Tg} \mathrm{yr}^{-1}$. Forty per cent of this uptake is located in the High Northern Hemisphere and 55\% is located in the Tropics. In terms of surface emissions, seasonality is mainly driven by biomass burning emissions. The inferred European anthropogenic emissions are consistent with independent $\mathrm{H}_{2}$ emissions estimated using a $\mathrm{H}_{2} / \mathrm{CO}$ mass ratio of 0.034 and $\mathrm{CO}$ emissions within the range of their respective uncertainties. Additional constraints, such as isotopic measurements would be needed to infer a more robust partition of $\mathrm{H}_{2}$ sources and sinks.

Published by Copernicus Publications on behalf of the European Geosciences Union. 


\section{Introduction}

With a mixing ratio of about $530 \mathrm{ppb}$ (parts per billion, $\left.10^{-9}\right), \mathrm{H}_{2}$ is the second most abundant reduced trace gas in the troposphere after methane $\left(\mathrm{CH}_{4}\right)$. In contrast to $\mathrm{CH}_{4}$ and other trace gases sharing anthropogenic sources, the observed $\mathrm{H}_{2}$ mixing ratios are lower in the Northern Hemisphere when compared to the Southern Hemisphere due to the distribution of the sources and sinks of $\mathrm{H}_{2}$ (Novelli et al., 1999). The strength of each term of the $\mathrm{H}_{2}$ budget is given hereafter as referred to in the literature (Novelli et al., 1999; Hauglustaine and Ehhalt, 2002; Sanderson et al., 2003; Rhee et al., 2006; Xiao et al., 2007; Price et al., 2007; Ehhalt and Rohrer, 2009) and compiled in Ehhalt and Rohrer (2009). The main sources of $\mathrm{H}_{2}$ are photochemical production by the transformation of formaldehyde (HCHO) in the atmosphere and incomplete combustion processes. Photolysis of $\mathrm{HCHO}$, a product in the oxidation chain of methane and other volatile organic compounds (VOCs) accounts for 31 to $77 \mathrm{Tg} \mathrm{yr}^{-1}$ and represents half of the total $\mathrm{H}_{2}$ source. Fossil fuel and biomass burning emissions, two incomplete combustion sources, account for similar shares of the global $\mathrm{H}_{2}$ budget $\left(5-25 \mathrm{Tg} \mathrm{yr}^{-1}\right) . \mathrm{H}_{2}$ emissions $\left(3-22 \mathrm{Tg} \mathrm{yr}^{-1}\right.$ ) originating from nitrogen fixation in the continental and marine biosphere complete the sources. $\mathrm{H}_{2}$ oxidation by free hydroxyl radicals $(\mathrm{OH})$ and enzymatic $\mathrm{H}_{2}$ destruction in soils must balance these sources because tropospheric $\mathrm{H}_{2}$ does not show a significant long term trend (Grant et al., 2010). $\mathrm{H}_{2}$ oxidation through $\mathrm{OH}$ accounts for 14 to $24 \mathrm{Tg} \mathrm{yr}^{-1}$, which is equivalent to $15 \%$ to $25 \%$ of the total $\mathrm{H}_{2}$ sink. $\mathrm{H}_{2}$ soil uptake, the major sink in the budget (40 to $90 \mathrm{Tg} \mathrm{yr}^{-1}$ or $75 \%$ to $85 \%$ of the total sink), is responsible for the observed latitudinal gradient. It is, however, relatively poorly constrained due to uncertainties regarding its associated physical and chemical processes. Specifically, $\mathrm{H}_{2}$ uptake is driven by enzymatic and microbial activities linked to $\mathrm{H}_{2}$ diffusivity, which depend mostly on soil moisture and temperature. The variations of these parameters lead to a seasonal cycle. In the Northern Hemisphere, the maximum uptake is observed at the end of summer/beginning of autumn when the temperatures are mild and the moisture is weak, leading to high bacterial activity and good diffusion of air in the soil. The minimum appears to be in spring when the soils are moist and cold, leading to a smaller bacterial activity and a slower diffusion of air in the soils (Conrad and Seiler, 1981, 1985; Yonemura et al., 1999, 2000a,b; Lallo et al., 2008, 2009; Schmitt et al., 2009).

Although global studies of $\mathrm{H}_{2}$ mixing ratios using observations from sampling networks began in the 1990s, Schmidt (1978) had already presented meridional profiles of the Atlantic Ocean from ship cruise measurements. Subsequently, Khalil and Rasmussen (1990) announced an increase in $\mathrm{H}_{2}$ mean mixing ratio based on weekly samplings between 1985 and 1989 at six locations from $71.5^{\circ} \mathrm{N}$ to $71.4^{\circ} \mathrm{S}$. Novelli et al. (1999) presented the first estimation of the $\mathrm{H}_{2}$ budget using observations from the NOAA Earth System Research Laboratory network (52 stations), which covers mainly the Northern Hemisphere but also to some extent the Southern Hemisphere with oceanic samplings and Antarctic sites. This network has been managed for $\mathrm{H}_{2}$ since 1989 with regards to the first sites and has been progressively extended to include all of the 52 sites in 1994. The CSIRO Global Flask Sampling Network (ten stations) began sampling in 1992 with a focus on the Southern Hemisphere (Langenfelds et al., 2002). Finally, within the AGAGE program (Advanced Global Atmospheric Gases Experiment), $\mathrm{H}_{2}$ has been measured continuously since 1993 at two stations (Prinn et al., 2000). A small increasing trend was extracted from the analysis of the observations provided by the NOAA network (Novelli et al., 1999) whereas the CSIRO observations exhibited a small decrease (Langenfelds et al., 2002). Since 2006, in the frame of the European project EUROHYDROS, a $\mathrm{H}_{2}$ monitoring network, focusing mainly on Europe (13 continuous and 11 flask sampling sites) but also worldwide through 7 flask sampling sites outside Europe, was developed (Engel, 2009). The French Atmospheric Network for Greenhouse Gases Monitoring (RAMCES), part of the Laboratory for Climate and Environmental Sciences (LSCE) has provided observations from 11 sites (one of them sampling continuously) to the EUROHYDROS network and contributed with 8 additional sites to this study.

Parallel to the observations, forward modelling studies were used to provide the first constraints on the $\mathrm{H}_{2}$ budget (Hauglustaine and Ehhalt, 2002; Price et al., 2007). Nevertheless, since the soil sink, the major loss term, is only known with large uncertainties, it is represented in models with more or less simplified assumptions which lead to a wide range of estimations for every term of the budget and especially for the soil sink, ranging from 40 to $90 \mathrm{Tg} \mathrm{yr}^{-1}$ (Ehhalt and Rohrer, 2009).

Atmospheric observations combined with a chemistrytransport model and prior information on surface fluxes and sources and sinks within the atmosphere allow us to retrieve the estimations of the $\mathrm{H}_{2}$ sources and sinks and their uncertainties within a Bayesian inversion framework. Atmospheric inversions have already been developed to study $\mathrm{H}_{2}$, but the studies remain sparse: Xiao et al. (2007) have used a 2D latitude-vertical 12 box model for atmospheric chemistry in an inversion framework combined with AGAGE, NOAA and CSIRO measurements to estimate the magnitude and variability of $\mathrm{H}_{2}$ sources and sinks for four semi-hemispheres over the 1993-2004 period. Pison et al. (2009) presented a first inversion of $\mathrm{H}_{2}$ using the same simplified chemistry scheme and model as in this study. More recently, Bousquet et al. (2011) have provided an analysis of global-tosub-continental details in the $\mathrm{H}_{2}$ budget before 2005 based on an optimisation system at sub-continental scale and using discrete observations from the flask networks of NOAA and CSIRO. 
Table 1. Flask sampling network sites (* RAMCES network (LSCE) sites additional to EUROHYDROS network). LSCE: Laboratoire des Sciences du Climat et de l'Environnement, France; MPI-BGC: Max Planck Institut für Biogeochemie, Germany; RHUL: Royal Holloway, University of London, UK; UHEI-IUP: Universität Heidelberg, Institut für Umweltphysik, Germany.

\begin{tabular}{|c|c|c|c|c|c|c|c|}
\hline Code & Site & Latitude $\left(^{\circ}\right)$ & Longitude $\left(^{\circ}\right)$ & Altitude (m) & $\begin{array}{r}\text { Beginning of } \\
\mathrm{H}_{2} \text { analysis } \\
(\mathrm{mm} / \mathrm{yy})\end{array}$ & Isotopes & Laboratories \\
\hline ALT & Alert & 82.45 & -62.52 & 210 & $05 / 07$ & no & LSCE \\
\hline ALT & Alert & 82.45 & -62.52 & 210 & $10 / 04$ & no & MPI-BGC \\
\hline ALT & Alert & 82.45 & -62.52 & 210 & $10 / 04$ & no & UHEI-IUP \\
\hline AMS & Amsterdam Island & -37.95 & 77.53 & 150 & $01 / 05$ & yes & LSCE \\
\hline BGU & Begur & 41.97 & 03.3 & 30 & $09 / 05$ & no & LSCE \\
\hline BIA & Bialystok & 53.14 & 23.01 & 182 & $01 / 05$ & no & MPI-BGC \\
\hline CGO* & Cape Grim & -40.68 & 144.68 & 94 & 03/06 & no & LSCE \\
\hline $\mathrm{CPT}$ & Cape Point & -34.35 & 18.48 & 260 & $03 / 05$ & no & LSCE \\
\hline CVR & Cabo Verde & 16.52 & -24.52 & 18 & 03/07 & yes & MPI-BGC \\
\hline FIK & Finokalia & 35.34 & 25.67 & 152 & $07 / 06$ & no & LSCE \\
\hline GRI* & Griffin & 56.62 & -03.78 & $800-2000$ & $02 / 06$ & no & LSCE \\
\hline HLE & Hanle & 32.78 & 78.96 & 4301 & $05 / 05$ & no & LSCE \\
\hline $\mathrm{HNG}^{*}$ & Hegyhatsal & 46.95 & 16.65 & 344 & $07 / 05$ & no & LSCE \\
\hline IVI* & Ivittuut & 61.20 & -48.18 & 15 & $09 / 07$ & no & LSCE \\
\hline LPO & Ile Grande & 48.80 & -03.57 & 30 & $02 / 06$ & no & LSCE \\
\hline MHD & Mace Head & 53.33 & -9.90 & 25 & $01 / 06$ & yes & LSCE \\
\hline NMY & Neumayer & -70.65 & -8.25 & 42 & $02 / 04$ & yes & UHEI \\
\hline OXK & Ochsenkopf & 53.14 & 23.01 & 1022 & $05 / 05$ & no & MPI-BGC \\
\hline ORL* & Orleans & 47.8 & 02.5 & $100-3000$ & $06 / 05$ & no & LSCE \\
\hline PDM & Pic du Midi & 42.93 & 0.13 & 2877 & $09 / 05$ & no & LSCE \\
\hline PON* & Pondichery & 12.01 & 79.86 & 30 & $09 / 06$ & no & LSCE \\
\hline PUY & Puy de Dôme & 45.77 & 02.97 & 1465 & 03/06 & no & LSCE \\
\hline $\mathrm{SCH}$ & Schauinsland & 47.92 & 7.92 & 1205 & $03 / 05$ & yes & UHEI-IUP \\
\hline SIS & Shetland Island & 60.05 & -1.15 & 30 & $10 / 03$ & no & MPI-BGC \\
\hline TRO & Troodos & 35.07 & -32.88 & 362 & 03/07 & no & RHUL \\
\hline TR3* & Trainou & 47.96 & 02.11 & 311 & 08/06 & no & LSCE \\
\hline TVR* & Tver & 82.45 & -62.52 & $500-3000$ & $08 / 04$ & no & LSCE \\
\hline ZOT & Zotino & 60.48 & 89.21 & 114 & $06 / 01$ & no & MPI-BGC \\
\hline
\end{tabular}

In this paper, we present the mixing ratio measurements of the RAMCES and EUROHYDROS sampling networks (13 continuous stations and 26 flasks sampling sites) for $\mathrm{H}_{2}$ between July 2006 and July 2009. These time series provide information on seasonal cycles and $\mathrm{H}_{2}$ distribution with latitude. As no NOAA data were available for this period, we have chosen to use only the data from the RAMCES and EUROHYDROS networks. The observations from mid-2006 to mid-2009 are assimilated in a variational inversion to estimate the global $\mathrm{H}_{2}$ budget. Contrary to Bousquet et al. (2011), the observations are continuous as well as discrete, from a more recent period and they are centred on Europe. Bousquet et al. (2011) showed that the 2000s flask network for $\mathrm{H}_{2}$ alone could constrain neither the different components of the $\mathrm{H}_{2}$ cycle, nor the regional fluxes. Nevertheless, we separately invert the different sources and sinks, at model resolution, in order to limit the aggregation error (Kaminski et al., 2000); if grouped before inversion, an error in the spatio-temporal distribution of $\mathrm{H}_{2}$ flux cannot be corrected properly by the inversion. Performing an analysis of the full uncertainties associated to every term of the budget laid however beyond the scope of this study. Therefore, we present the results for large latitudinal bands with a focus on soil uptake. As the density of measurements in time and space is much higher in Europe than in Bousquet et al. (2011) for the late 2000s, we also discuss specifically the European sources and sinks. Six different scenarios have been elaborated to progressively constrain the $\mathrm{H}_{2}$ soil uptake. We focus first on the sensitivity of the soil uptake to different spatio-temporal distributions and second on the European emission distribution, Europe being the best constrained part of the world ( 28 of the 38 sites are located in Europe). 
Table 2. EUROHYDROS continuous stations. AGH-UST: University of Science and Technology, Poland; EMPA: Swiss Federal Institut for Materials Science and Technology, Switzerland FMI: Finnish Meteorological Institute, Finland; LSCE: Laboratoire des Sciences du Climat et de l'Environnement, France; MGO: Main Geophysical Observatory, Russia; NILU: Norsk Institutt for Luftforskning, Norway; RHUL: Royal Holloway, University of London, UK; UEA, University of East Anglia, UK; UFRA: Institut für Meteorologie und Geophysik, GoetheUniversität Frankfurt, Germany; UHEI-IUP: Institut für Umweltphysik, Universität Heidelberg, Germany; UNIURB: Universit degli Studi di Urbino, Italy; UOB: University of Bristol, UK.

\begin{tabular}{|c|c|c|c|c|c|c|}
\hline Code & Site & Latitude $\left(^{\circ}\right)$ & Longitude $\left(^{\circ}\right)$ & Altitude (m) & $\begin{array}{l}\text { Beginning of } \mathrm{H}_{2} \\
\text { analysis }(\mathrm{mm} / \mathrm{yy})\end{array}$ & Laboratories \\
\hline EGH & Egham & 51.42 & 00.55 & 41 & $01 / 07$ & RHUL \\
\hline GIF & Gif sur Yvette & 48.70 & 02.01 & 20 & $06 / 06$ & LSCE \\
\hline HEI & Heidelberg & 49.40 & 08.70 & 116 & $01 / 05$ & UHEI-IUP \\
\hline HEL & Helsinki & 60.20 & 24.96 & 50 & 06/07 & FMI \\
\hline JUN & Jungfraujoch & 46.55 & 7.98 & 3580 & $08 / 05$ & EMPA \\
\hline KRK & Krakow & 50.02 & 19.92 & 220 & $01 / 06$ & AGH-UST \\
\hline MHD & Mace Head & 53.33 & -9.90 & 25 & $01 / 06$ & UOB \\
\hline MTC & Monte Cimone & 44.17 & 10.68 & 2165 & $08 / 07$ & UNIURB \\
\hline PAL & Pallas & 66.97 & 24.12 & 565 & $09 / 06$ & FMI \\
\hline TNS & Taunus observatory & 50.22 & 8.45 & 825 & $10 / 06$ & UFRA \\
\hline VKV & Voeikovo & 59.95 & 30.7 & 72 & 08/07 & MGO \\
\hline WAO & Weybourne & 52.95 & 1.12 & 31 & 03/08 & UEA \\
\hline ZEP & Zeppelin & 78.90 & 11.88 & 474 & $01 / 06$ & NILU \\
\hline
\end{tabular}

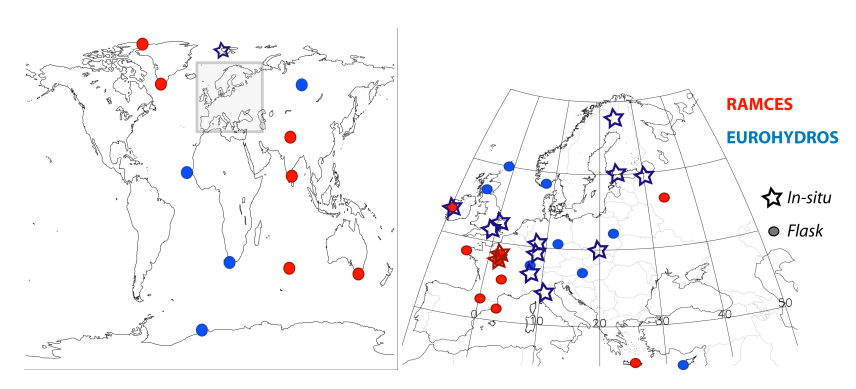

Fig. 1. EUROHYDROS and RAMCES sampling sites used in this study.

\section{Observational network}

\subsection{RAMCES flask sampling network}

RAMCES network's central laboratory is located in Gif-surYvette (GIF) near Paris, France. During the period between 2006 and 2009, the RAMCES network analysed air from 19 globally distributed sites (see Fig. 1). At eighteen sites, flasks were sampled weekly or fortnightly. At Gif-sur-Yvette, air is sampled continuously. Table 1 lists the RAMCES flask network sites used in this study (highlighted with an asterisk for the sites additional to the EUROHYDROS network). They are distributed across latitudes from $40^{\circ} \mathrm{S}$ to $82^{\circ} \mathrm{N}$ and most of them provide access to background air that is representative of zonal mean atmospheric composition. At the sites of Tver (Russia), Hegyhatsal (Hungary), Griffin (Scottland) and Orléans (France), monthly to weekly light aircraft flights have sampled the troposphere between 100 and
$3000 \mathrm{~m}$. These sites were part of the CARBOEUROPE program that ended in December 2008. Trainou (France), Puy de Dôme (France), Pic du Midi (France) and Hanle (India) are situated inland but, except for Trainou, which regularly encounters polluted air masses, they are away from local anthropogenic influences. All of the other ground sites are coastal and they encounter air masses of maritime origin.

\subsection{EUROHYDROS network}

In the EUROHYDROS project (September 2006 to September 2009), twenty laboratories from ten different countries participated. In this study, atmospheric $\mathrm{H}_{2}$ measurements at 30 sites performed by 13 laboratories running over the period 2006 to 2009, are used in the variational inversion (see Table 1, Table 2 and Fig. 1). At 13 sites, ambient air is continuously sampled. For two stations (Alert (Canada) and Mace Head (Ireland)), simultaneous sampling by different laboratories is performed. Six stations (Egham (UK), Gif-surYvette (France), Heidelberg (Germany), Helsinki (Finland), Krakow (Poland), Voeikovo (Russia)) sample air in urban or suburban conditions. Continental sites such as Schauinsland (Germany) encounter alternatively clean and moderately polluted air masses. At Mace Head, Finokalia (Greece), Troodos (Cyprus) and Begur (Spain), the sampled air is under clean maritime and moderately polluted influences. The remaining stations mainly encounter clean background air. For six sites (Alert, Mace Head, Schauinsland, Cabo Verde, Amsterdam Island and Neumayer (Antarctica)), hydrogen isotopes in the sampled flasks are analysed by the University of Utrecht. 
During the project, $\mathrm{H}_{2}$ soil deposition velocities were estimated at different sites and with different methods (Lallo et al., 2008, 2009; Schmitt et al., 2009; Hammer and Levin, 2009; Yver et al., 2009; Schillert, 2010). These flux estimations were interpolated into a deposition velocity map as detailed in Sect. 3.3.

\subsection{Sampling technique}

In the framework of the EUROHYDROS project, all laboratories were requested to follow the recommendations for good measurement practice, a protocol developed at the beginning of the project (Engel, 2009). The calibration and non-linearity correction strategy, the type of standard gas cylinders, pressure regulators and instrumental set-up were specified there. In particular, all samples were measured using standard cylinders calibrated against the MPI2009 scale, which has been elaborated for the EUROHYDROS project (Jordan and Steinberg, 2011).

Within the RAMCES network, we followed this strategy as described in detail in Yver et al. (2009). Briefly, a commercial gas chromatograph coupled with a reduction gas detector (RGD) from Peak Laboratories, Inc., California, USA is used to measure $\mathrm{H}_{2}$ via the reduction of mercuric oxide and the detection of mercury vapour by UV absorption. Sixteen inlet ports are set up on a 16-port Valco valve to connect flask samples to the inlet system. To avoid contamination and reduce the flushing volume of the sample when measuring the flasks, all sample inlet lines can be separately evacuated. Pairs of flasks are sampled at the sites as a rule, to check for sampling error or any malfunction in the sampling equipment. Each flask is then analysed twice to check the reproducibility of the measurements. Statistics on pair and double injection analyses give a reproducibility below $1 \%$ $(\approx 3 \mathrm{ppb})$.

The analysis technique for atmospheric $\mathrm{H}_{2}$ within the EUROHYDROS network is for most laboratories also based on the separation with gas chromatography and the detection with a RGD. The methods, following the recommendations for good measurement practice, are described for some of the laboratories in the following papers: Bonasoni et al. (1997) for UNIURB (see Tables 1 and 2 for complete name), Hammer et al. (2009); Hammer and Levin (2009) for UHEI-IUP, Aalto et al. (2009) for FMI, Grant et al. (2010) for UOB and Bond et al. (2010) for EMPA. At the flask sites, air is generally sampled fortnightly.

To ensure the compatibility of the data of the different laboratories, regular calibration against the common scale but also comparison of measurements done at the same site (Alert or Mace Head for example) and comparison exercises (Star Robin and Round Robin) were performed. From these last comparisons, the agreement between the 13 laboratories was better than 1.4\% (Engel, 2009).
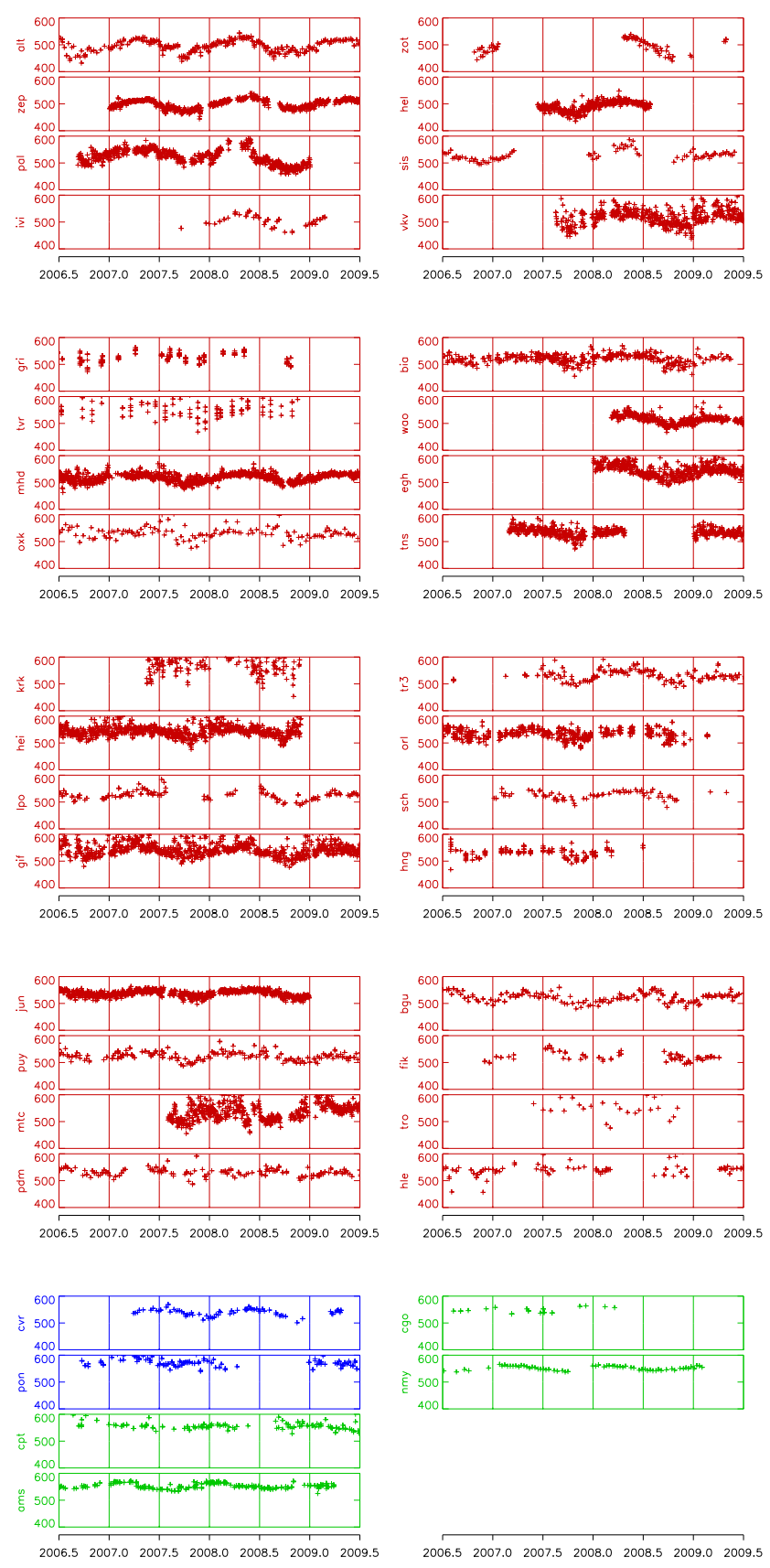

Fig. 2. $\mathrm{H}_{2}$ time series of sampling sites from RAMCES and EUROHYDROS networks. Measurements are performed by 13 different European laboratories (see Table 1 and Table 2). The Northern Hemisphere sites are plotted in red, the tropical sites in blue and the Southern Hemisphere sites in green.

\subsection{Observations used in the inversion}

The observations from the 38 RAMCES and EUROHYDROS sites are plotted in Fig. 2. The figure presents the sites by latitude, from the north to the south. No sites are present in the Southern Tropics (between $0^{\circ}$ and $30^{\circ} \mathrm{S}$ ). For 


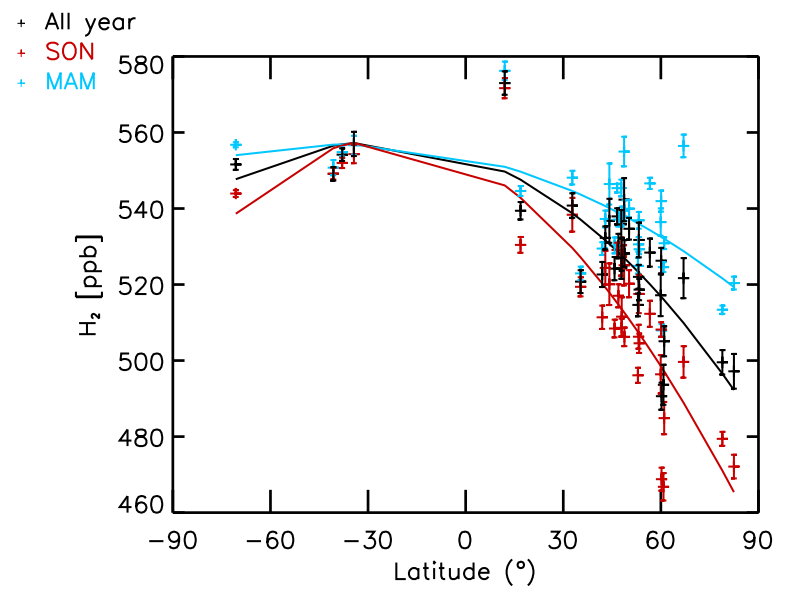

Fig. 3. $\mathrm{H}_{2}$ mean mixing ratio latitudinal gradient. In black, for the whole year, in blue, for March, April, May (MAM) and in red for September, October and November (SON).

the continuous stations, the daily means are plotted and mixing ratios above $800 \mathrm{ppb}$, which correspond to strong local pollution events, are excluded. No other filters are applied to the data. At Tver, Griffin and Orléans, vertical profiles are plotted leading to the observed large scatter. The mean mixing ratios range from $\approx 500 \mathrm{ppb}$ at Alert to $\approx 550 \mathrm{ppb}$ at Neumayer with a maximum in the Tropics $(\approx 570 \mathrm{ppb}$ at Pondichery (India)). We observe a seasonal cycle at all sites but with a larger amplitude and deeper minima in the High Northern Hemisphere $\left(\mathrm{HNH}, 30-90^{\circ} \mathrm{N}\right)$. In this hemisphere, the seasonal maximum (up to $540 \mathrm{ppb}$ ) occurs in the spring (April, May) and the minimum of $\approx 430 \mathrm{ppb}$ is observed in the autumn (September, October). In the Northern Tropics (between $30^{\circ} \mathrm{N}$ and $0^{\circ}$ ), the seasonal cycle is shifted by about two months (maximum in July and minimum in December), whereas in the High Southern Hemisphere ( $\mathrm{HSH}, 30-90^{\circ} \mathrm{S}$ ), the seasonal maximum occurs in the austral summer (January, February) reaching up to $580 \mathrm{ppb}$ and the minimum occurs in austral winter (July, August) equaling $550 \mathrm{ppb}$. The maximum amplitude is found in the $\mathrm{HNH}$ with about $110 \mathrm{ppb}$ peak-to-trough and the minimum is found in the $\mathrm{HSH}$ with $30 \mathrm{ppb}$ peak-to-trough. These patterns reflect the differences in the location and timing of $\mathrm{H}_{2}$ sources and sinks. In the $\mathrm{HSH}$ and the Tropics, the seasonal variations are mostly explained by the timing of biomass burning emissions and photochemical production, which peak in the summer. The HSH minima, higher than in the $\mathrm{HNH}$, can be explained by the smaller influence of soil uptake in the HSH due to the smaller soil surface area in the HSH than in the HNH. In the HNH, the minimum is reached in the autumn when soil uptake is still significant after its late summer maximum, and the photochemical production is rapidly decreasing compared to the summer. The maximum occurs in the spring when the soil uptake is the weakest and the photochemical production is increasing fast (Schillert, 2010).
In Fig. 3, the mean mixing ratio calculated over 2006-2009 for every site, except for the urban sites such as Heidelberg (Germany), Krakow (Poland) and Egham (London suburb, UK) where the anthropogenic pollution enhances the background level of $\mathrm{H}_{2}$ and for the sites where the vertical profiles are plotted, is plotted against latitude. As already described, the lower mixing ratios are measured in the HNH. Mean mixing ratios show an increase with decreasing latitudes until $30^{\circ} \mathrm{S}$ and then show a slight decrease from $30^{\circ} \mathrm{S}$ to $70^{\circ} \mathrm{S}$. From the north to the south, the mean gradient is $\approx 0.4 \mathrm{ppb} /{ }^{\circ}$ leading to a $50 \mathrm{ppb}$ difference and from the north to the Southern Tropics, it is $\approx 0.5 \mathrm{ppb} /{ }^{\circ}$ i.e. $60 \mathrm{ppb}$ difference. The latitudinal gradient is plotted in September/October/November in red and in March/April/May in blue. As expected, in the $\mathrm{HNH}$, the mixing ratios are lower in the autumn than they are in the spring. The latitudinal difference is also larger in the autumn with $\approx 70 \mathrm{ppb}$ than it is in the spring ( $\approx 35 \mathrm{ppb})$.

These patterns highlight the importance of soil uptake in the spatiotemporal variations of the $\mathrm{H}_{2}$ mixing ratios and the need for improved estimations of its strength and variations.

\section{The variational inversion system}

\subsection{General settings of PYVAR/LMDz-SACS}

We use a framework which combines three components: the inversion system PYVAR developed by Chevallier et al. (2005), the transport model LMDz (Hourdin and Talagrand, 2006) and a simplified chemistry module called SACS (Simplified Atmospheric Chemistry System) (Pison et al., 2009). Briefly, LMDz is used with nineteen hybrid-pressure levels in the vertical (first level thickness of $150 \mathrm{~m}$, resolution in the boundary layer of 300 to $500 \mathrm{~m}$ and $\approx 2 \mathrm{~km}$ at the tropopause) and a horizontal resolution of $3.75^{\circ} \times 2.5^{\circ}$ (longitude-latitude). The air mass fluxes used off-line are pre-calculated by the LMDz online GCM nudged towards the ECMWF analyses for horizontal winds. SACS is a simplified methane oxidation chain. SACS keeps only the main species and the major reactions in this chemical chain. The intermediate reactions are regarded as very fast compared to the principal reactions. In the atmosphere, the oxidation by $\mathrm{OH}$ is the main sink of $\mathrm{CH}_{4}$. This reaction is the first in a chain of photochemical transformations which lead to formaldehyde. Formaldehyde is also produced from the degradation of volatile organic compounds (VOCs) in the continental boundary layer. $\mathrm{H}_{2}$ is at the end of the reaction chain along with $\mathrm{CO}$ as a product of the transformation of formaldehyde:

$\mathrm{HCHO}+\mathrm{h} v \longrightarrow \mathrm{H}_{2}+\mathrm{CO}$

Although $\mathrm{OH}$ is the essential modulator in this reaction chain, it is not easily measurable on a global scale. Its concentration is estimated in the model in an indirect way: using methyl chloroform $\left(\mathrm{CH}_{3} \mathrm{CCl}_{3}\right.$ or $\left.\mathrm{MCF}\right)$ which reacts only 
with $\mathrm{OH}$ and the sources of which are quantified with acceptable accuracy (Krol et al., 2003; Prinn et al., 2005; Bousquet et al., 2005). The adequacy of SACS with the chemistry model INCA (Interactive Chemistry and Aerosols) (Folberth et al., 2005) is evaluated in Pison et al. (2009). These authors show that the differences between the two chemistry models are significantly smaller than the variability of the concentration fields of the species of interest. To obtain the initial conditions for the simulations with SACS, the full chemistry-transport model LMDz-INCA is used to establish 3-D fields of $\mathrm{OH}$ and VOCs that are consistent with the initial state of the system (Hauglustaine et al., 2004). The reaction constants and photolysis rates are also given to PYVAR by LMDz-INCA (Hauglustaine and Ehhalt, 2002). SACS can be used to estimate the sources and sinks of $\mathrm{CH}_{4}, \mathrm{CO}, \mathrm{HCHO}$ and $\mathrm{H}_{2}$ (Pison et al., 2009). In this work, we focus only on $\mathrm{H}_{2}$ and the fluxes of $\mathrm{HCHO}, \mathrm{CO}$ and $\mathrm{CH}_{4}$ are assumed to be optimised and their errors are set to $\pm 1 \%$ of the maximum flux in the grid cell over the inversion period, whereas the errors on $\mathrm{H}_{2}$ are set to $\pm 100 \%$.

PYVAR is a Bayesian inference scheme formulated in a variational framework. It consists in the minimisation of a cost function $J(\boldsymbol{x})$ :

$J(x)=\left(x-x_{b}\right)^{T} \mathbf{B}^{-1}\left(x-x_{b}\right)+(\mathcal{H}(x)-\mathbf{y})^{T} \mathbf{R}^{-1}(\mathcal{H}(x)-\mathbf{y})$

where $\boldsymbol{x}$ is the state vector containing the variables that need to be estimated at each model grid cell, $\boldsymbol{x}_{b}$ contains the prior values of the variables, $y$ contains the observations and $\mathcal{H}$ is the operator representing the chemistry-transport model and the simulated concentrations at the same time and location than the measurements. $\mathbf{B}$ and $\mathbf{R}$ are the covariance matrices of the error statistics of $\boldsymbol{x}_{b}$ and $\mathbf{y}$, respectively. These errors are considered unbiased and Gaussian. The state vector contains the emission fluxes (here for $\mathrm{H}_{2}$ ) and the average production of $\mathrm{HCHO}$ in each cell at an eight-day frequency, the average $\mathrm{OH}$ concentrations as described by Bousquet et al. (2005) (four latitudinal bands) at the same frequency and the initial conditions for the concentrations (here of $\mathrm{H}_{2}$ ). The eight-day frequency of the state vector is chosen as a compromise between a high time resolution and a reasonable computational time. Moreover, it is also a compromise between the time resolution of flasks (weekly to fortnightly) and of daily means calculated from continuous observations. The system finds the optimal $\boldsymbol{x}_{a}$ which fits the observations and the prior values as weighted by the covariance matrices $\mathbf{R}$ and B. Physical considerations and educated guess as described in Chevallier et al. (2005), are used to infer the errors (variances, spatial and temporal correlations) of the prior. In this study, the errors are set to $\pm 100 \%$ of the maximum flux in the grid cell over the inversion period for $\mathrm{H}_{2}, \pm 1 \%$ of the flux for $\mathrm{MCF}$ (in order to constrain $\mathrm{OH}$ ), $\mathrm{CO}, \mathrm{CH}_{4}$ and $\mathrm{HCHO}$. The error of $\pm 10 \%$ for $\mathrm{OH}$ concentrations is consistent with the differences between estimates of the $\mathrm{OH}$ concentrations of several studies (Krol et al., 2003; Prinn et al., 2005; Bousquet et al., 2005). Finally, the error on the initial concen- trations of $\mathrm{HCHO}, \mathrm{MCF}$ and $\mathrm{H}_{2}$ is set at $\pm 10 \%$. Temporal correlations are neglected as the state vector is aggregated on an eight-day basis. The spatial correlations are defined by an e-folding length of $500 \mathrm{~km}$ over land and $1000 \mathrm{~km}$ over sea and no-correlation between land and sea. The observation error matrix $\mathbf{R}$ combines the measurement errors, the model errors (transport and chemistry) and the representation errors (i.e. the impact of the relatively coarse resolution system in the representation of pointwise measurements). We neglect cross-correlation terms, which makes $\mathbf{R}$ diagonal. For the diagonal elements of $\mathbf{R}$ (variances), we use the variability of the double sampling measurement as proxy for the observation error, with a corresponding ceiling standard deviation of $\pm 5 \mathrm{ppb}$ for $\mathrm{H}_{2}$ and $\pm 1.2 \mathrm{ppt}$ for MCF.

In the original version of the inversion which constitutes scenario $\mathrm{S} 0$ in this study, the $\mathrm{H}_{2}$ prior emissions and monthly deposition velocity maps are as detailed in Hauglustaine and Ehhalt (2002). Briefly, as no emission inventory exists for $\mathrm{H}_{2}$ emissions and as $\mathrm{CO}$ and $\mathrm{H}_{2}$ share the same sources (transportation, biomass burning, methane and VOCs oxidation), the distribution of $\mathrm{H}_{2}$ emissions is inferred from the distribution of CO emissions (Olivier et al., 1996; Granier et al., 1996; Brasseur et al., 1998; Hao et al., 1996). Emissions are then scaled to fit the estimates given by the various studies presented in Hauglustaine and Ehhalt (2002). $\mathrm{N}_{2}$ fixationrelated emissions are scaled from $\mathrm{CO}$ emission maps for marine emissions and from NOx emission maps for terrestrial emissions (Erickson and Taylor, 1992; Müller, 1992). Finally, the deposition velocities are estimated using the dry deposition velocities for $\mathrm{CO}$, which are based on net primary production (NPP) variations and a ratio between the deposition velocities of $\mathrm{H}_{2}$ and $\mathrm{CO}$ of 1.5 (Hough, 1991; Brasseur et al., 1998; Hauglustaine and Ehhalt, 2002). This leads to deposition velocities between zero and $0.1 \mathrm{~cm} \mathrm{~s}^{-1}$. Alternative scenarios for soil uptake are presented in Sect. 3.3.

\subsection{New developments in PYVAR/LMDz-SACS}

In the version presented by Pison et al. (2009), the net flux of $\mathrm{H}_{2}$ is inverted at the model resolution without separating the sources from the sinks. Only the $\mathrm{OH}$ sink can be calculated separately as the result of the optimisation of the concentration of $\mathrm{OH}$. At each time step, the $\mathrm{H}_{2}$ soil uptake is calculated according to:

$\mathrm{H}_{2 \text { deposited }}=v_{\text {dep }}\left[H_{2}\right]$

with $v_{\text {dep }}$ representing a constant velocity at each pixel and time step read from the prior monthly deposition velocity map and $\left[\mathrm{H}_{2}\right]$ representing the mixing ratio. The soil uptake is then modified via the mixing ratio but the deposition velocities remain constant.

In this work, we have modified the code to completely optimise the soil uptake by adding the deposition velocity specifically as an unknown variable in the state vector. Thus, $v_{\text {dep }}$ is optimised at each time step and grid cell. In 


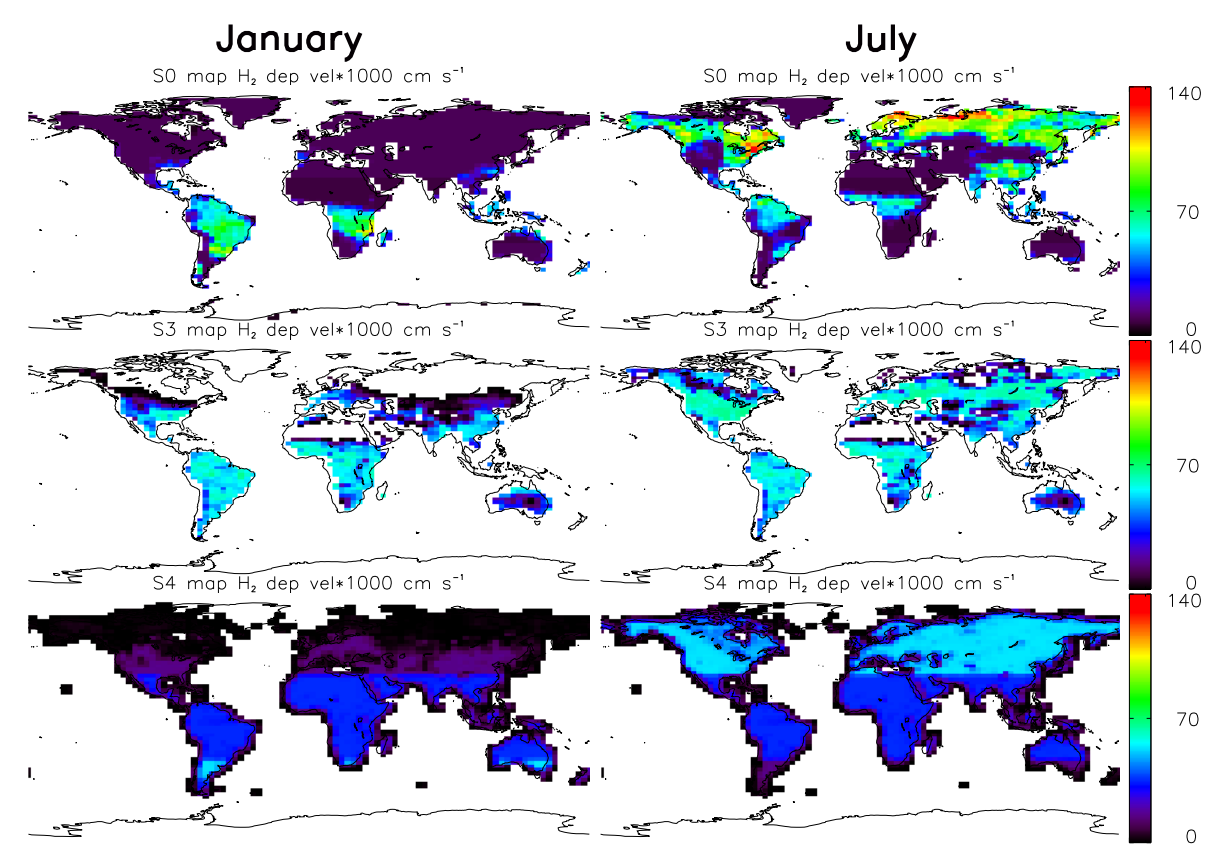

Fig. 4. The three soil deposition velocity maps used in this study. Top: from Hauglustaine and Ehhalt (2002), middle: from Sitch et al. (2003), bottom: from Oslo CTM2 based on Schillert (2010). White pixels are missing values.

Table 3. Scenarios used in this study.

\begin{tabular}{lll}
\hline Scenario & Model & Prior \\
\hline S0 & original settings $\left(\mathrm{H}_{2}\right.$ net flux inverted) & original settings (as in Pison et al. (2009) \\
S1 & original settings & new fluxes and new initial mixing ratios \\
S2 & separate sink & new fluxes and new initial mixing ratios \\
S3 & separate sink with LPJ deposition velocity map & new fluxes and new initial mixing ratios \\
S4 & separate sink with EUROHYDROS deposition velocity map & new fluxes and new initial mixing ratios \\
S5 & separate sink and sources (biomass burning, fossil fuel and others) with & new fluxes and new initial mixing ratios \\
& EUROHYDROS deposition velocity map & \\
\hline
\end{tabular}

a further attempt to optimise each term of the $\mathrm{H}_{2}$ budget, the sources are also separately inverted. The emissions are split into three components: fossil fuel, biomass burning and $\mathrm{N}_{2}$ fixation-related emissions. Prior fossil fuel and biomass burning emissions are inferred from the recent bottom-up CO emission inventory from Lamarque et al. (2010), by applying a mass flux ratio $\mathrm{H}_{2} / \mathrm{CO}$ of 0.034 and 0.02 , respectively (Hauglustaine and Ehhalt, 2002; Yver et al., 2009). $\mathrm{N}_{2}$ fixation-related emissions remain as they were in the previous version and represent about $25 \%$ of the total emissions. The concentrations of $\mathrm{HCHO}$ are also optimised using satellite measurements from OMI for several 3-D large regions (one scaling factor per 3-D region and per year) as described in Bousquet et al. (2011).

\subsection{Scenarios elaborated for the inversion}

Six scenarios have been elaborated (see Table 3 ). In scenario $\mathrm{S} 0$, we invert the net flux of $\mathrm{H}_{2}$ using the emission and de- position velocity maps from Hauglustaine and Ehhalt (2002) as described previously. The first-guess modelling leads to a strong offset with a simulated mean mixing ratio $\approx 115 \mathrm{ppb}$ higher than observed. Hauglustaine and Ehhalt (2002) attributed this mismatch between model and data to the underestimation of the soil sink in the Northern Hemisphere during winter and spring. Moreover, using the same scenario, Pison et al. (2009) found an urrealistic accumulation of $\mathrm{H}_{2}$ in the atmosphere attributed partly to the same cause.

In scenario $\mathrm{S} 1$, we scale the initial mean mixing ratios to the observed mean mixing ratios. Moreover, we use updated prior surface emission fluxes from Lamarque et al. (2010) with $\mathrm{H}_{2} / \mathrm{CO}$ mass ratio of 0.034 and 0.02 for anthropogenic and biomass burning emissions, respectively (Hauglustaine and Ehhalt, 2002; Yver et al., 2009) and optimised HCHO concentrations from Bousquet et al. (2011). The deposition velocity map is scaled by a ratio of 1.28 to take into account the hypothesised underestimation and produce a better 
balanced budget assuming that the other terms (production, emission and $\mathrm{OH}$ loss) are known and fixed.

In scenarios $\mathrm{S} 2$ to $\mathrm{S} 4$, the deposition velocity is optimised separately from the emissions and for each scenario, a different prior soil deposition velocity map is used. The S2 deposition velocity map is the same as that of S1. A bottom-up soil uptake estimation calculated by the Lund-Postdam-Jena Dynamic Global Vegetation Model (LPJ) (Sitch et al., 2003) yields the map for S3. This model combines process-based, large-scale representations of terrestrial vegetation dynamics (with feedbacks through canopy conductance between photosynthesis and transpiration) and land-atmosphere carbon and water exchanges in a modular framework. The $\mathrm{H}_{2}$ soil uptake is estimated based on the assumption that it is mainly driven by molecular diffusion. The uptake is then expressed using Fick's law and depends of the mixing ratio at the surface, the diffusivity of $\mathrm{H}_{2}$ in the soil and the oxidation constant rate. The diffusivity in the soil itself depends of the soil porosity and temperature whereas the oxidation rate depends of soil temperature, moisture and organic content. This submodel is integrated into the LPJ model. The soil properties are based on the Food and Agriculture Organization (FAO) data set overlain by soil organic carbon data from the IGBP-DIS data set (Group, 2000). Soil temperature and moisture are given by LPJ. $\mathrm{H}_{2}$ mixing ratio is fixed at $531 \mathrm{ppb}$. Zero values are applied on oceans and wetlands and when the snow layer is higher than $50 \mathrm{~cm}$ or when the NPP is lower than $10 \mathrm{gC} \mathrm{m}^{-2} \mathrm{yr}^{-1}$ (Morfopoulos et al., 2010).

For S4, the monthly map was produced for the EUROHYDROS project by the Oslo CTM2, an Eulerian chemical transport model (Søvde et al., 2008), in combination with soil deposition velocities estimated within the project with bottom-up and top-down methods compiled in Schillert (2010). Mean values and seasonal cycles are given for three latitudinal bands: HNH, Tropics and HSH. As the estimations for the HSH are sparse, the seasonal cycle in the HSH is the same as in the HNH but shifted of 6 months. The Oslo CTM2 couples the ECMWF IFS meteorological data and the MODIS annual L3 global 0.05 Deg landcover map, to EUROHYDROS deposition velocities to take into account the latitudinal distribution and also the effect of snow and wetlands.

Finally, in scenario S5, surface emissions are further separated into three components: fossil fuel, biomass burning and $\mathrm{N}_{2}$ fixation-related emissions. Scenario S5 uses the prior deposition velocity map from $\mathrm{S} 4$.

\subsection{Characteristics of the soil deposition velocity maps}

As stated in the previous paragraph, we use three different soil deposition velocity maps as prior in the model. These maps are shown in Fig. 4 for the months of January and July. They present some common large scale features but differ for the magnitude and distribution of regional deposition velocity. On a global scale, the highest values are found in
July corresponding to the favorable temperature and moisture conditions for high deposition. In January, the maximum values are located in the Southern Hemisphere (austral summer) and in July they are located in the Northern Hemisphere except for the S3 map where high deposition velocities are found in the Southern Hemisphere throughout the year. The first two maps (S0 and S3) are more detailed since they are based on vegetation maps. The last one (S4) was created using deposition velocity measurements combined with the driving meteorology of the Oslo CTM2. These measurements remain sparse and were thus extrapolated to latitudinal bands. The first map (S0) includes the highest grid cell velocities, up to $0.14 \mathrm{~cm} \mathrm{~s}^{-1}$ in July in the Northern Hemisphere, whereas in the S3 and S4 maps the maximum grid cell deposition velocity reaches only $0.07 \mathrm{~cm} \mathrm{~s}^{-1}$ and $0.06 \mathrm{~cm} \mathrm{~s}^{-1}$ respectively. S0 presents important spatiotemporal variations with marked hotspots. In the winter, these hotspots are observed in Brazil and southern Africa (United Republic of Tanzania, Republic of Mozambique, Zambia and Angola). In summer, hotspots are observed mostly in North America and in the north of Russia. These high values are due to the direct link existing between NPP and deposition velocities in the assumptions of scenario S0: high NPP produced by favorable meteorological conditions may lead to too high deposition velocities. In the Southern Hemisphere, these hotspots reach $0.1 \mathrm{~cm} \mathrm{~s}^{-1}$ in a grid cell while in the Northern Hemisphere, they reach up to $0.14 \mathrm{~cm} \mathrm{~s}^{-1}$ in a grid cell. In Lallo et al. (2008), the highest values found in the boreal forest was $0.07 \mathrm{~cm} \mathrm{~s}^{-1}$ which is about two times lower than the values here. These high deposition velocities are then to be considered with caution, as possible artifacts of the use of NPP as a proxy of $\mathrm{H}_{2}$ deposition velocity.

S3 is characterised by the absence of large spatiotemporal variations. In this map, the deposition velocity is lower north of $30^{\circ} \mathrm{N}$ than south of this latitude (except for the Sahara region with the desert and Australia).

In S4 map, the latitudinal deposition velocity presents spatiotemporal variations, but contrary to S0, there are no hotspots. In winter, the larger values are found in South America and southern Africa too (Argentina and South Africa). Since the soil uptake is extrapolated from latitudinal bands, there are also large values in southern Australia. In summer, the higher deposition velocities are observed north of $30^{\circ} \mathrm{N}$.

Due to the large distribution differences shown in Fig. 4, we can expect to find important differences in the first-guess simulations.

\section{Results and discussion}

\subsection{Evaluation of the first-guess and inverse simulations}

In Fig. 5, we present the simulated and observed mixing ratios for four sites: the northernmost site, Alert in Alaska, a 


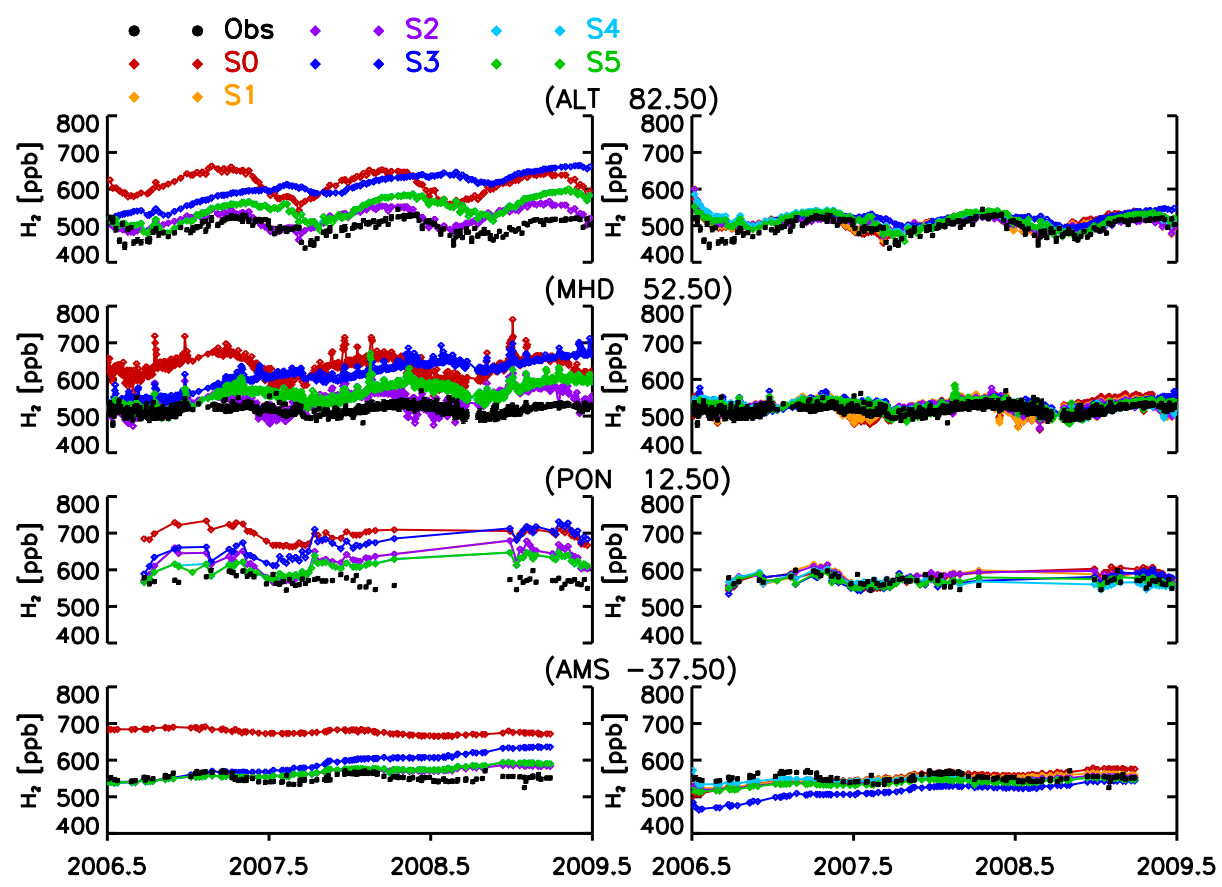

Fig. 5. $\mathrm{H}_{2}$ mixing ratios at Alert, Mace Head, Pondichery and Amsterdam Island. Black filled circles plot the observations, diamonds, simulated mixing ratios. Each scenario is represented by a different color, S0 and S1 in a red color scale, S2 to S4 in a blue color scale and S5 in green. On the left panel, the prior simulations and on the right panel, the posterior simulations.

mid-latitudinal site, Mace Head in Ireland, a northern tropical site, Pondichery in India and a southern hemispheric site, Amsterdam Island. Observations are plotted with black filled circles. Simulated mixing ratios are plotted in coloured diamonds with first-guess mixing ratios modelled with the prior emissions on the left panel and inverted mixing ratios on the right panel. As S1 and S2 as well as S4 and S5 use the same prior information, their first-guess mixing ratios are superimposed.

As previously mentioned, the first-guess mixing ratios using prior emissions from S0 are overestimated by about $115 \mathrm{ppb}$. For the other scenarios, the initial mixing ratios have been adjusted and the prior fluxes have been updated so that the mean difference is lower than $40 \mathrm{ppb}$, except for S3, which presents a mean difference of $87 \mathrm{ppb}$ due to a drift in time as the prior budget is not balanced. At Alert, the first-guess simulated seasonal cycle of S0 to S2 follows the observed cycle with a maximum in autumn and a minimum at the beginning of spring. For S3 through S5, the seasonal cycle is about two months late. At Mace Head, on the contrary, the first-guess simulated seasonal cycle of S0 to S2 is about two months in advance, whereas S3, S4 and S5 follow the observed cycle. For the other sites, the weak seasonal cycle is well reproduced. The first-guess mixing ratios of S3, S4 and S5 present a qualitatively better agreement with the observed seasonal cycle at all sites. The seasonal amplitude is fairly well represented by all of the first-guess simulations except for S3, for which the seasonal amplitude is weaker.
For all sites, the first-guess mixing ratios of S3, S4 and S5 present a drift of 50, 30 and $30 \mathrm{ppb} \mathrm{yr}^{-1}$ respectively. This is due to the fact that the prior $\mathrm{H}_{2}$ budget is not balanced since we use different soil deposition maps. We also see a slight decrease in S0 first-guess mixing ratios for Amsterdam Island which is not observed in the measurements.

After inversion, as expected, the simulated mixing ratios fit the observations better in terms of amplitude as well as seasonal cycle. The mean difference between observations and simulated mixing ratios is thus close to zero. The mean coefficient of correlation between the observations and the simulations increases from 0.2 to 0.5 . The better correlation for the scenarios including the separate soil uptake optimisation is found for $\mathrm{S} 4$ with a mean difference around $-1.5 \mathrm{ppb}$ $(+35 \mathrm{ppb}$ for the first-guess), a standard deviation of $17 \mathrm{ppb}$ (47 ppb for the first-guess) and a coefficient of correlation of 0.6 ( 0.4 for the first-guess). S5, where the sources are further separated, presents very close results (mean difference $1.8 \mathrm{ppb}$, standard deviation $18 \mathrm{ppb}$ and coefficient of correlation of 0.6).

\subsection{Inverted fluxes}

For each process in the $\mathrm{H}_{2}$ budget, the flux interannual variations remain small, below $\pm 5 \mathrm{Tg} \mathrm{yr}^{-1}$. All of the scenarios are consistent for the interannual variations in terms of pattern and amplitude (not shown). In Fig. 6, the mean seasonal cycle for each flux in 2006-2009 is plotted after inversion 


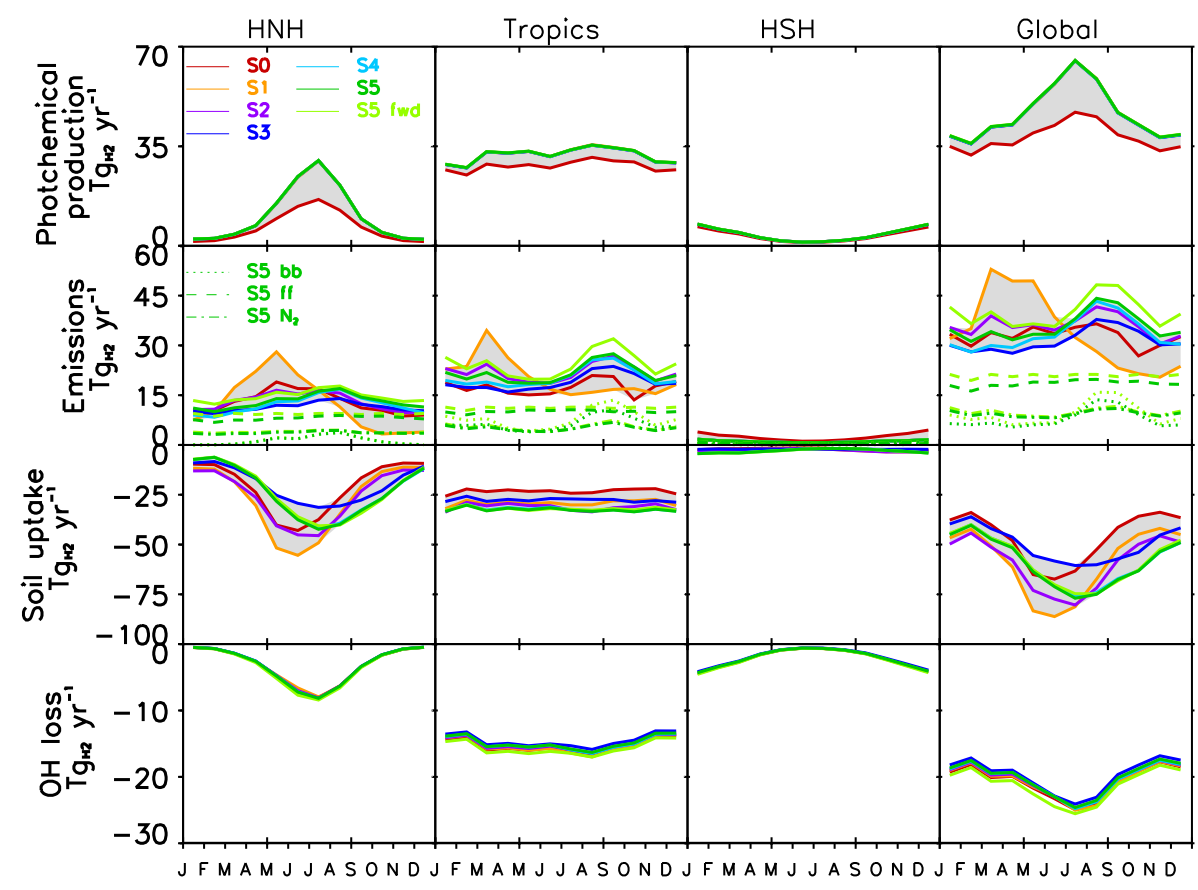

Fig. 6. Posterior seasonal cycle of $\mathrm{H}_{2}$ fluxes for four regions (HNH: High North Hemisphere, $30-90^{\circ} \mathrm{N}$; Tropics, between $30^{\circ} \mathrm{N}$ and $30^{\circ}$ S; HSH: High Southern Hemisphere, $30-90^{\circ} \mathrm{S}$ ). Each scenario is represented by a different color, S0 and S1 in red scale, S2 to S4 in blue scale and S5 in green. The prior emissions for the S5 scenario are plotted in light green and labelled S5 fwd. Separated emissions of S5 and S5 fwd are plotted with dots for the biomass burning emissions, with dashes for the anthropogenic emissions and with dashes-dots for the $\mathrm{N}_{2}$ fixation-related emissions. The grey shaded area represents the spread between the different scenarios.

for all of the scenarios. The prior fluxes of S5 are added for comparison. As S4 and S5 differs only by the separation of the sources, the inverted fluxes for the sinks and for the $\mathrm{HCHO}$ source are superimposed. For each process, we have studied three regions: the High Northern Hemisphere (HNH) north of $30^{\circ} \mathrm{N}$, the Tropics, between $30^{\circ} \mathrm{N}$ and $30^{\circ} \mathrm{S}$ and the High Southern Hemisphere (HSH) south of $30^{\circ} \mathrm{S}$. As explained before, $\mathrm{H}_{2}$ photochemical production and $\mathrm{OH}$ loss are strongly constrained and therefore, the inverted fluxes stay close to the prior fluxes. The difference of $\approx 5 \mathrm{Tg} \mathrm{yr}^{-1}$ between $\mathrm{S} 0$ and the other scenarios for the photochemical production is due to the change of the prior $\mathrm{HCHO}$ concentrations between the first scenario and the others. An error of $\pm 100 \%$ has been assigned to the prior deposition velocity and to the emissions and these ones are therefore more subject to changes. The soil uptake seasonal cycle presents large variations in the HNH. S0 and S1, where the deposition velocity is not separately inverted, exhibit their maximum in June. For S2, with the separated inversion of the deposition velocity, the maximum is shifted to July and for S3, S4 and $\mathrm{S} 5$, the maximum is shifted to August. In comparison, the soil uptake values, obtained with bottom-up and top-down methods, are maximum at the end of August or the beginning of September (Schillert, 2010). Moreover, the observed mixing ratios, which are dominated by the uptake in the $\mathrm{HNH}$, are minimum at the end of summer as well. The shift from
June to August shows that we are able to reproduce the seasonal cycle of the soil uptake better than with the previous assumptions. In the Tropics and the HSH, no seasonal cycle is apparent and the mean value is consistent among all of the scenarios.

In S0, it was supposed that the soil sink was too weak in the HNH (Hauglustaine and Ehhalt, 2002) producing an accumulation of $\mathrm{H}_{2}$ in the atmosphere, so in $\mathrm{S} 1$ and $\mathrm{S} 2$ we have increased the prior deposition velocities by $30 \%$ to better balance the budget. In $\mathrm{S} 1$, we still invert the net $\mathrm{H}_{2}$ flux and the soil sink remains nearly the same as the prior flux. In S2, since we separately invert the deposition velocity and the surface emissions, the deposition velocities are optimised and the resulting HNH soil uptake is nearly back to the value of S0. This seems to imply that the soil uptake in S0 was not that weak but that the offset between the simulated mixing ratios and observations has other causes. Errors in the regional distribution of deposition velocities or in emission strength are possible explanation for such an offset.

Overall, the seasonal cycle of the surface emissions peaks in the HNH in June for S0 to S2 and in August for S3 to S5. This can be explained by the change in the seasonality of the soil uptake which shifts from June to August as well, highlighting the fact that the different processes are not independently inverted. In the Tropics, two maxima are observed, one in March and the second in September. They 
coincide with the biomass burning maxima of each hemisphere, in March in the south and in August/September in the north (van der Werf et al., 2006). Bousquet et al. (2011) found two peaks as well, the first one in mid-March and the second, which is also the larger one, in September. S2, S4 and $\mathrm{S} 5$ reproduce this same pattern. The southern maximum is clearly apparent for S1, S2 and S5 but weak for S0, S3 and S4. Except for S1, the second maximum in September is larger. We observe a good agreement among all of the scenarios, except for S0 and S1, for the amplitude of the summer peak. In the Southern Hemisphere, there are only very small surface emissions.

In S5, we have separately inverted the emissions in three different processes. Biomass burning (dark green dots), anthropogenic (dark green dashes) and $\mathrm{N}_{2}$ fixation-related (dark green dashes-dots) emissions are plotted in the same panel as the total surface emissions. The prior is overplotted in light green with the same symbols for each source. The seasonality is mainly driven by the biomass burning emissions whereas the anthropogenic and $\mathrm{N}_{2}$ fixation-related emissions are more or less constant throughout the year.

From the analysis of the differences between the observations and the simulated mixing ratios and from the comparison of the timing of the modelled soil uptake and biomass burning emissions with the measured fluxes, it can be concluded that S5 is the more pertinent scenario. Therefore, the following discussion on the $\mathrm{H}_{2}$ budget focuses on the results of this scenario.

\section{$4.3 \quad \mathrm{H}_{2}$ budget}

In Table 4, the mean estimation for each term of the global and regional budget is calculated for 2007, 2008 and the whole period based on scenario S5. The global estimations for each term as given in Xiao et al. (2007) and Bousquet et al. (2011) are added in Table 4. Estimating the uncertainties of the posterior fluxes can be done using the MonteCarlo approach of Chevallier et al. (2007). However, due the large computational cost of this method, a simpler approach was preferred. The one-sigma uncertainties are estimated from the spread of the difference between each scenario compared to reference scenario S5 for each flux. We do not include $\mathrm{SO}$ because, in this scenario, the prior $\mathrm{HCHO}$ flux is $\approx 5 \mathrm{Tg} \mathrm{yr}^{-1}$ lower than the prior flux in the other scenarios and, as explained previously, prescribed with small uncertainties. Moreover, the uncertainties of Table 4 do not include all sources of uncertainties. For instance, they do not account explicitly for transport model errors, for chemistry model errors, or for uncertainties in the inversion setup other than the distribution of deposition velocities. They should therefore be considered as lower estimates. Performing an analysis of the full uncertainties associated to the values in Table 4 is an important and complex matter which lays beyond the scope of this work. For Bousquet et al. (2011), we have indicated the standard deviation of the sensitivity
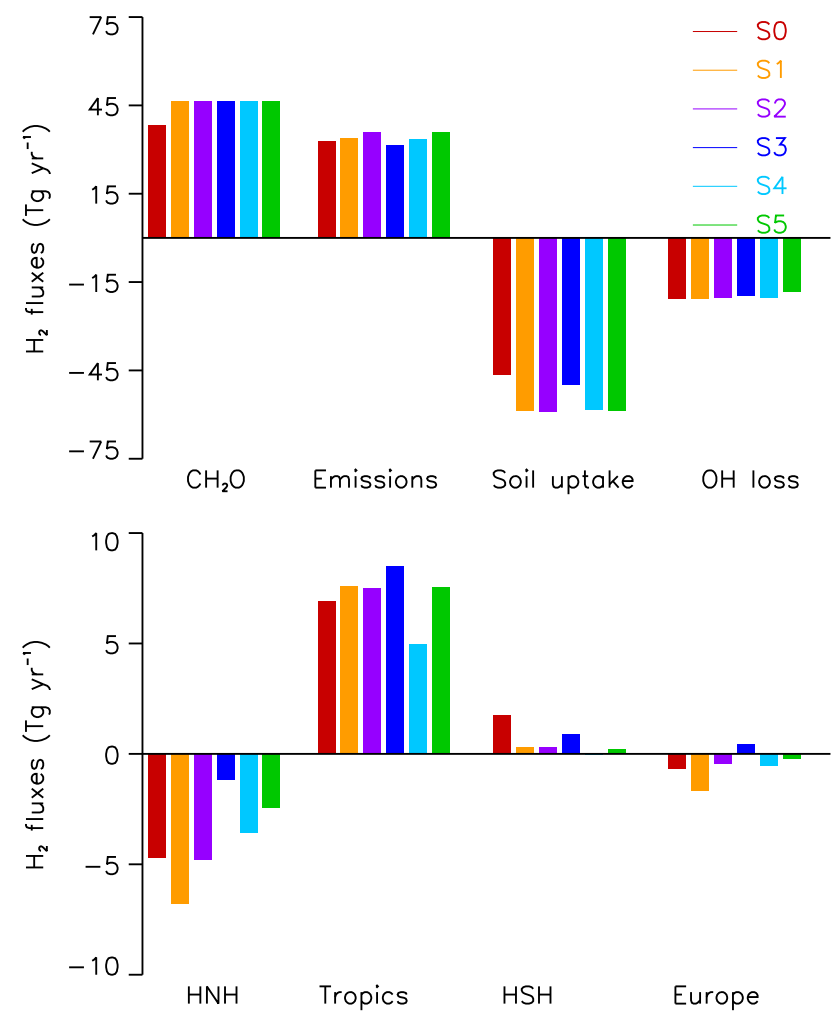

Fig. 7. Posterior $\mathrm{H}_{2}$ budget per process (above) and regions (below). Each colour bar represents a scenario.

inversions based on the reference scenario (external errors). The errors in Xiao et al. (2007) include model uncertainties, absolute calibration error and errors in the assumed fossil fuel source strength. For each region, we indicate the relative proportion of each regional source or sink in comparison with the global source or sink. Figure 7 represents this budget per process and per region. All of the scenarios produce a consistent process-based view (maximum spread of $9.0 \mathrm{Tg} \mathrm{yr}^{-1}$ ). From a region-based view, the total $\mathrm{H}_{2}$ flux ranges between -8 and $+8 \mathrm{Tg} \mathrm{yr}^{-1}$ with a maximum spread of $4 \mathrm{Tg} \mathrm{yr}^{-1}$ (not shown). For all of the scenarios, the $\mathrm{HNH}$ is a net sink of $\mathrm{H}_{2}$ and the Tropics are a net source. Globally, $\approx 47 \mathrm{Tg} \mathrm{yr}^{-1}$ of $\mathrm{H}_{2}$ are produced by photochemical production and $\approx 18 \mathrm{Tg} \mathrm{yr}^{-1}$ are consumed by the $\mathrm{OH}$ reaction. Approximately $36 \mathrm{Tg} \mathrm{yr}^{-1}$ are emitted and $\approx 59 \mathrm{Tg} \mathrm{yr}^{-1}$ are deposited in the soils. This budget leads to a tropospheric burden of $166 \mathrm{Tg}$ and a life time of 2.2 years. This budget is consistent with most of the previous studies about $\mathrm{H}_{2}$ cycle such as Ehhalt and Rohrer (2009) who published a tropospheric burden of $155 \mathrm{Tg}$ and a life time of 2.0 years.

Every process has a larger flux in the Tropics than it has in the HNH or HSH. Tropical processes represent between 55\% and $74 \%$ of global processes depending on the flux types. Indeed, the photochemical production and the $\mathrm{OH}$ sink depend strongly on insolation which has its maximum in the Tropics. 
Table 4. $\mathrm{H}_{2}$ budget per process in $\mathrm{Tg} \mathrm{yr}^{-1}$ ( ${ }^{*}$ in Bousquet et al. (2011) the fossil fuel and $\mathrm{N}_{2}$ fixation related emissions are inverted together). The indicated error represents the maximum spread of the scenarios S1 to S4 compared to S5 for this study, the standard deviation of the sensitivity inversions for Bousquet et al. (2011) and for Xiao et al. (2007), the model uncertainties, absolute calibration error and errors in the assumed fossil fuel source strength. The \% represent the part of each regional term in the global term. The separated emission terms are not associated with error in this study as we did not perform several sensitivity tests.

\begin{tabular}{|c|c|c|c|c|c|}
\hline Global & 2007 & 2008 & mid 2006-mid 2009 & & \\
\hline & & & $\begin{array}{l}\text { This } \\
\text { study }\end{array}$ & $\begin{array}{l}\text { Bousquet } \\
\text { et al. } \\
(2011)\end{array}$ & $\begin{array}{l}\text { Xiao } \\
\text { et al. } \\
(2007)\end{array}$ \\
\hline Biomass Burning & 7.8 & 7.7 & 7.8 & $10 \pm 2$ & $12 \pm 3$ \\
\hline Fossil fuel & 18.8 & 18.3 & 18.5 & $22 \pm 3^{*}$ & $15 \pm 10$ \\
\hline $\mathrm{N}_{2}$ fixation & 9.5 & 9.4 & 9.4 & * & - \\
\hline Emissions & $36.0 \pm 5.4$ & $35.4 \pm 5.5$ & $35.7 \pm 4.3$ & $32 \pm 5$ & $27 \pm 9$ \\
\hline Photochemical production & $46.9 \pm 0.1$ & $46.5 \pm 0.2$ & $46.5 \pm 0.2$ & $48 \pm 4$ & $76 \pm 13$ \\
\hline $\mathrm{OH}$ loss & $-18.1 \pm 0.5$ & $-18.2 \pm 0.4$ & $-18.2 \pm 0.4$ & $-18 \pm 1$ & $-18 \pm 3$ \\
\hline Soil uptake & $-58.0 \pm 8.6$ & $-59.9 \pm 8.6$ & $-58.8 \pm 9.0$ & $-62 \pm 3$ & $-84 \pm 8$ \\
\hline North hemisphere & 2007 & 2008 & mid 2006-mid 2009 & & \\
\hline Biomass Burning & 1.3 & 1.3 & 1.3 & & \\
\hline Fossil fuel & 8.3 & 8.0 & 8.0 & & \\
\hline $\mathrm{N}_{2}$ fixation & 3.7 & 3.7 & 3.7 & & \\
\hline Emissions & $13.3 \pm 1.7$ & $13.0 \pm 2.6$ & $13.0 \pm 1.7(36 \%)$ & $50 \%$ & $37 \%$ \\
\hline Photochemical production & $10.7 \pm 0.1$ & $10.6 \pm 0.1$ & $10.6 \pm 0.0(23 \%)$ & $33 \%$ & $17 \%$ \\
\hline $\mathrm{OH}$ loss & $-2.9 \pm 0.1$ & $-2.9 \pm 0.1$ & $-2.9 \pm 0.1(16 \%)$ & $22 \%$ & $12 \%$ \\
\hline Soil uptake & $-22.5 \pm 3.3$ & $-23.8 \pm 2.9$ & $-23.3 \pm 3.6(40 \%)$ & $53 \%$ & $39 \%$ \\
\hline Tropics & 2007 & 2008 & mid 2006-mid 2009 & & \\
\hline Biomass Burning & 6.3 & 6.3 & 6.4 & & \\
\hline Fossil fuel & 10.2 & 10.0 & 10.1 & & \\
\hline $\mathrm{N}_{2}$ fixation & 5.1 & 5.1 & 5.1 & & \\
\hline Emissions & $21.6 \pm 3.6$ & $21.3 \pm 3.0$ & $21.6 \pm 3.0(61 \%)$ & $47 \%$ & $62 \%$ \\
\hline Photochemical production & $32.2 \pm 0.1$ & $31.9 \pm 0.1$ & $31.9 \pm 0.1(69 \%)$ & $38 \%$ & $75 \%$ \\
\hline $\mathrm{OH}$ loss & $-13.4 \pm 0.5$ & $-13.4 \pm 0.5$ & $-13.4 \pm 0.5(74 \%)$ & $50 \%$ & $77 \%$ \\
\hline Soil uptake & $-32.5 \pm 4.5$ & $-33.0 \pm 4.7$ & $-32.6 \pm 4.9(55 \%)$ & $18 \%$ & $55 \%$ \\
\hline South hemisphere & 2007 & 2008 & mid 2006-mid 2009 & & \\
\hline Biomass Burning & 0.1 & 0.1 & 0.1 & & \\
\hline Fossil fuel & 0.4 & 0.4 & 0.4 & & \\
\hline $\mathrm{N}_{2}$ fixation & 0.6 & 0.6 & 0.6 & & \\
\hline Emissions & $1.1 \pm 0.0$ & $1.1 \pm 0.0$ & $1.1 \pm 0.0(3 \%)$ & $3 \%$ & $1 \%$ \\
\hline Photochemical production & $4.1 \pm 0.0$ & $4.0 \pm 0.0$ & $4.0 \pm 0.0(8 \%)$ & $29 \%$ & $8 \%$ \\
\hline $\mathrm{OH}$ loss & $-1.9 \pm 0.1$ & $-1.9 \pm 0.1$ & $-1.9 \pm 0.1(10 \%)$ & $28 \%$ & $11 \%$ \\
\hline Soil uptake & $-3.0 \pm 0.9$ & $-3.0 \pm 0.9$ & $-3.0 \pm 0.9(5 \%)$ & $29 \%$ & $6 \%$ \\
\hline
\end{tabular}

The tropical maximum in the surface emissions is due to biomass burning emissions. For the maximum of soil uptake in the Tropics (55\%), as Xiao et al. (2007) have already proposed, one explanation could be that the tropical soils are more efficient in terms of uptake than the extra-tropical soils. It could also be linked to the optimum conditions in the humidity and temperature of this region. The soil sink in the HNH nevertheless represents $40 \%$ of the global soil sink.
The mean values of the global budget remain, within the uncertainties, compatible with the one presented in Bousquet et al. (2011). The budget from Xiao et al. (2007) differs significantly except for the $\mathrm{OH}$ loss. Their emissions are lower but their photochemical production and their soil uptake are more than $20 \mathrm{Tg} \mathrm{yr}^{-1}$ larger than in our work. The distribution between the different regions is more consistent with Xiao et al. (2007) than with Bousquet et al. (2011). This result is explained by the fact that, in our study and in Xiao et al. (2007), the budget was analysed through the same three 


\section{Emissions}
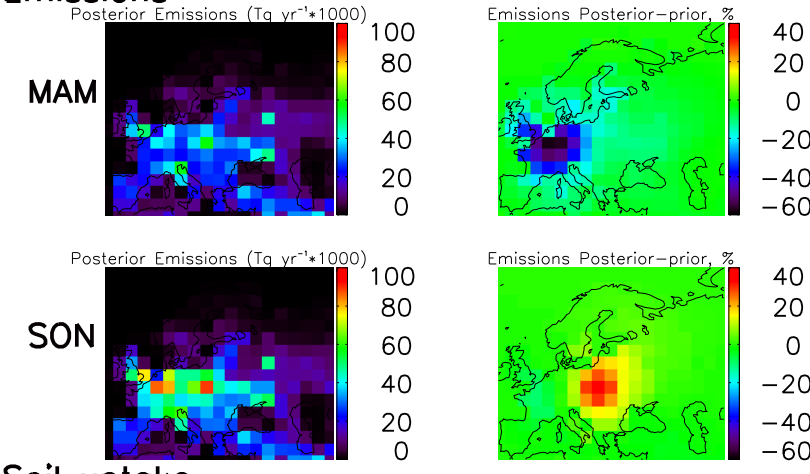

Soil uptake
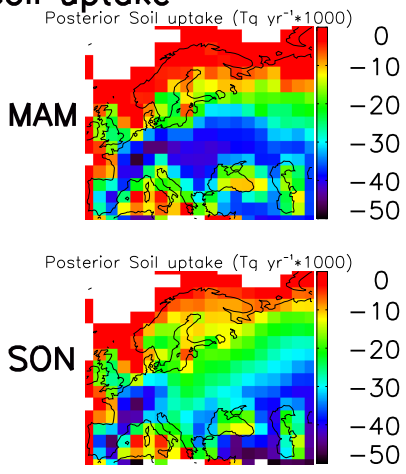

40

20

$-40$

$-60$
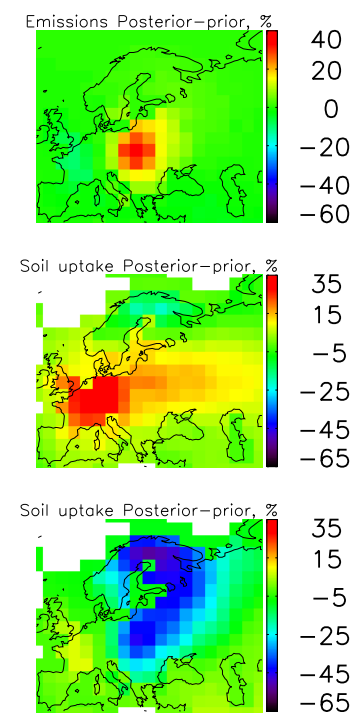

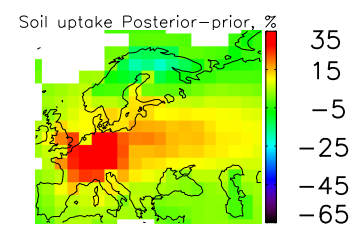

Fig. 8. S5 posterior flux map (on the left) and difference between $\mathrm{S} 5$ posterior and prior in $\%$ of the prior (on the right) fluxes for the surface emissions (above) and soil uptake (below) zoomed on Europe for March, April and May (MAM) and September, October and November (SON). Missing values are plotted in white.

latitudinal bands, whereas Bousquet et al. (2011) used large regions that do not exactly fit these latitudinal bands. Finally, our estimate of biomass burning emissions is of the same order of magnitude as Bousquet et al. (2011) and Xiao et al. (2007) but our estimation represents only $22 \%$ of the total emissions against $31 \%$ and $44 \%$ for Bousquet et al. (2011) and Xiao et al. (2007), respectively.

\subsection{Focus on Europe}

In this study, Europe exhibits the largest number of observation sites, therefore being the best constrained area of the world for an atmospheric inversion. As seen in Fig. 7, Europe, as part of the $\mathrm{HNH}$, seems to be a net sink of $\mathrm{H}_{2}$. In Fig. 8, the posterior flux map and the difference between posterior and prior in percentage of the prior for the S5 surface emissions and soil uptake are plotted. The emissions in Europe present the same pattern in the spring and autumn. However, in the autumn, the emissions are slightly higher (grid cell maximum of $0.8 \mathrm{Tg} \mathrm{yr}^{-1}$ ) than they are in the spring (grid cell maximum of $0.5 \mathrm{Tg} \mathrm{yr}^{-1}$ ). This autumn flux can be explained from the seasonal cycle (see Fig. 6), by a combination of enhanced biomass burning and $\mathrm{N}_{2}$ fixation-

related emissions at the end of the summer and a small increase of the anthropogenic emissions at the end of the year. The differences between prior and posterior range from -60 to $0 \%$ in spring and from -15 to $+30 \%$ in autumn for the emissions. This means that in spring, the inversion reduces European prior emissions, especially in western Europe. In autumn, western prior emissions are only slightly decreased, but eastern prior emissions are largely increased by the inversion. As expected, the spring soil uptake is smaller than the autumn soil uptake especially in the boreal region and the south of Europe. The uptake in central Europe, smaller in autumn than in summer, may be explained by early snow in the alpine region in autumn. The differences between prior and posterior range from -7 to $+35 \%$ in spring and from -58 to $+10 \%$ in autumn. The spring soil uptake is increased in all of Europe compared to the prior estimate. In autumn, a large decrease of the prior soil uptake is found for northern Europe, whereas western Europe fluxes are increased compared to the prior.

In Table 5, the emissions and the soil uptake are detailed for seven countries or groups of countries: geographical Europe (including the European part of Russia, west of the Ural mountains); Europe (27 countries); France; Germany; the United Kingdom and Ireland; Scandinavia and Finland; Spain, Italy and Portugal. In terms of emissions, geographical Europe represents $6 \%$ and $18 \%$ of the global and $\mathrm{HNH}$ emissions respectively. The European soil uptake accounts for $7 \%$ and $17 \%$ of the global and $\mathrm{HNH}$ uptake, respectively. Anthropogenic emissions account for $52 \%$ of the total emissions globally, $62 \%$ in the $\mathrm{HNH}$ and $72 \%$ in Europe (27 countries). In Europe, depending on the countries, anthropogenic emissions account for $50 \%$ to $100 \%$ of the total emissions. As written above, there is no bottom-up inventory of $\mathrm{H}_{2}$ emissions. We have then compared our results with the inventory from the Institut für Energiewirtschaft und Rationelle Energieanwendung (IER) (Thiruchittampalam and Köble, 2004), which is not used as prior information (see Table 5). We have scaled the $\mathrm{CO}$ emissions with the anthropogenic $\mathrm{H}_{2} / \mathrm{CO}$ mass ratio of 0.034 as found in Yver et al. (2009). The two sets of values agree well with one another. The mean difference lies around $10 \%$. Uncertainties on inventories are not yet produced quantitatively but the EDGAR database has proposed ranges of uncertainties: low $( \pm 10 \%)$, medium $( \pm 50 \%)$ and large $( \pm 100 \%)$ (Olivier et al., 1996). For $\mathrm{CO}$, most uncertainties by source types are reported as "medium", therefore making our results consistent with IER estimates, within their respective uncertainties.

\section{Conclusions}

This work presents the results of an inversion of tropospheric $\mathrm{H}_{2}$ sources and sinks at a grid cell resolution for the period between mid-2006 and mid-2009. It focuses on soil uptake and surface emissions. Overall, the results of this study 
Table 5. $\mathrm{H}_{2}$ budget per country in Europe in $\mathrm{Tg}_{\mathrm{yr}}-1$. The indicated error represents the maximum spread of the scenarios $\mathrm{S} 1$ to $\mathrm{S} 4$ compared to S5 for the emissions and of the scenarios S2 to S4 compared to S5 for the soil uptake as the soil uptake is not inverted in scenario S1. In bold, the anthropogenic emissions from S5. In italics, the anthropogenic emissions from IER. (Thiruchittampalam and Köble, 2004)

\begin{tabular}{lccccc}
\hline Emissions $\left(\mathrm{Tg} \mathrm{yr}^{-1}\right)$ & 2007 & 2008 & \multicolumn{3}{c}{ mid 2006-mid 2009 } \\
\hline & & & Total & Anthropogenic & Anthropogenic from IER \\
Europe (geographical) & $2.2 \pm 0.4$ & $2.3 \pm 0.6$ & $2.2 \pm 0.3$ & $\mathbf{1 . 4}$ & 1.5 \\
Europe (27) & $1.2 \pm 0.3$ & $1.4 \pm 0.4$ & $1.3 \pm 0.2$ & $\mathbf{0 . 9}$ & 0.2 \\
France & $0.2 \pm 0.1$ & $0.2 \pm 0.1$ & $0.2<0.1$ & $\mathbf{0 . 2}$ & 0.1 \\
Germany & $0.2 \pm 0.1$ & $0.2 \pm 0.1$ & $0.2 \pm 0.1$ & $\mathbf{0 . 1}$ & 0.1 \\
UK + Ireland & $0.1<0.1$ & $0.1<0.1$ & $0.1<0.1$ & $\mathbf{0 . 1}$ & 0.1 \\
Scandinavia + Finland & $0.1<0.1$ & $0.1<0.1$ & $0.1<0.1$ & $\mathbf{0 . 1}$ & 0.2 \\
Spain+Italy+Portugal & $0.3<0.1$ & $0.3<0.1$ & $0.3<0.1$ & $\mathbf{0 . 2}$ & mid 2006-mid 2009 \\
\hline Soil uptake (Tg yr ${ }^{-1}$ ) & 2007 & 2008 & & $-3.9 \pm 0.7$ & \\
\hline Europe (geographical) & $-3.9 \pm 0.7$ & $-4.0 \pm 0.7$ & & $-1.6 \pm 0.3$ & \\
Europe (27) & $-1.6 \pm 0.3$ & $-1.7 \pm 0.3$ & & $-0.3<0.1$ & \\
France & $-0.3<0.1$ & $-0.3<0.1$ & & $-0.1 \pm 0.1$ & \\
Germany & $-0.2<0.1$ & $-0.2<0.1$ & & $-0.3 \pm 0.2$ & \\
UK + Ireland & $-0.1 \pm 0.1$ & $0.0 \pm 0.1$ & & $-0.3 \pm 0.2$ & \\
Scandinavia + Finland & $-0.3 \pm 0.2$ & $-0.4 \pm 0.2$ & & & \\
Spain+Italy+Portugal & $-0.3 \pm 0.2$ & $-0.3 \pm 0.2$ & & & \\
\hline
\end{tabular}

agree with previous studies with regard to a lifetime of about two years, a soil uptake of $\approx-59 \mathrm{Tg} \mathrm{yr}^{-1}$ and emissions of $\approx 36 \mathrm{Tg} \mathrm{yr}^{-1}$ for a total source of $\approx 83 \mathrm{Tg} \mathrm{yr}^{-1}$. The inversions performed from six different scenarios are fairly consistent with one another in terms of physical processes involved (maximum spread of $9 \mathrm{Tg} \mathrm{yr}^{-1}$ ) and of flux location (maximum spread of $4 \mathrm{Tg} \mathrm{yr}^{-1}$ ). From the several scenarios that have been elaborated, the best one (S5) in terms of fit to the mean atmospheric mixing ratio, seasonal cycle and flux measurements combines a separate inversion of the soil sink and of the sources in three terms and a soil deposition velocity map based on soil uptake measurements. Our estimation for the global soil uptake is $-59 \pm 9 \mathrm{Tg} \mathrm{yr}^{-1}$. $95 \%$ of this uptake is located in the HNH (40\%) and the Tropics (55\%). No significant trend is found for the soil uptake or any of the other processes of the $\mathrm{H}_{2}$ budget throughout 2006-2009. To study the emissions better, scenario S5 with a separate inversion of the sources in three processes (biomass burning, fossil fuel and $\mathrm{N}_{2}$ fixation-related emissions) shows that the seasonal variability of the emissions is mainly driven by the biomass burning emissions. Finally, we have focused our analysis on Europe and compared the anthropogenic emissions with a $\mathrm{CO}$ inventory scaled with a $\mathrm{H}_{2} / \mathrm{CO}$ mass ratio of 0.034. Anthropogenic emissions represent $50 \%$ to $100 \%$ of the total emissions depending on the country. The model and the inventory estimates agree with one another within their respective uncertainties. A further step will be to invert other relevant species with $\mathrm{H}_{2}$ such as $\mathrm{CH}_{4}, \mathrm{CO}$ and $\mathrm{HCHO}$, which is a unique capability of our multispecies inversion system (Pison et al., 2009). In particular, the optimisation of the
HCHO 3-D production, which is fixed in this work, would have an important influence on the $\mathrm{H}_{2}$ budget through the process of photochemical production. Performing an analysis of the full uncertainties associated to each term of the budget will be an important but complex further step.

Future inversions of $\mathrm{H}_{2}$ sources and sinks should gain robustness by including observations of other networks but also by including observations of the deuterium enrichment of $\mathrm{H}_{2}\left(\delta D\right.$ of $\left.\mathrm{H}_{2}\right)$, as shown in Rhee et al. (2006); Price et al. (2007). Several groups have produced $\delta D$ observations (Gerst and Quay, 2001; Rahn et al., 2003; Röckmann et al., 2003; Rhee et al., 2006; Price et al., 2007). Within the EUROHYDROS project, $\delta D$ observations from six sampling sites are available for the recent years (from 2006). The isotopic signatures for fossil fuel, biofuel, biomass burning, and ocean sources are all depleted in D relative to the atmosphere, whereas photochemical production of $\mathrm{H}_{2}$ has a large positive isotopic signature. On the sink side, the isotopic fractionation during $\mathrm{OH}$ loss is greater than the fractionnation from soil uptake (Price et al., 2007). The tropospheric $\delta D$ is about $+130 \pm 4 \%$ (Gerst and Quay, 2000). Assimilating $\delta D$ observations together with $\mathrm{H}_{2}$ observations could bring new constraints on $\mathrm{H}_{2}$ budget if the different isotopic signatures can be determined with sufficient precision.

Acknowledgements. We gratefully thank Mathilde Grand and Vincent Bazantay for performing the flasks and in-situ analyses for the RAMCES network as well as the people involved in the samplings and analyses for the EUROHYDROS network. Thank you to the computing support team of the LSCE. This work was carried out under the auspices of the 6th EU framework program 
\# FP6-2005-Global-4 "EUROHYDROS- A European Network for Atmospheric Hydrogen Observations and Studies". RAMCES is funded by INSU and CEA.

Edited by: M. Heimann

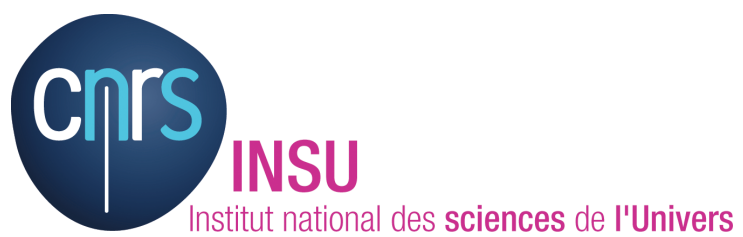

The publication of this article is financed by CNRS-INSU.

\section{References}

Aalto, T., Lallo, M., Hatakka, J., and Laurila, T.: Atmospheric hydrogen variations and traffic emissions at an urban site in Finland, Atmos. Chem. Phys., 9, 7387-7396, doi:10.5194/acp-97387-2009, 2009.

Bonasoni, P., Calzolari, F., Colombo, T., Corazza, E., Santaguida, R., and Tesi, G.: Continuous $\mathrm{CO}$ and $\mathrm{H}_{2}$ measurements at Mt. Cimone (Italy): Preliminary results, Atmos. Environ., 31, 959967, 1997.

Bond, S., Vollmer, M., Steinbacher, M., Henne, S., and Reimann, S.: Atmospheric molecular hydrogen $\left(\mathrm{H}_{2}\right)$ : Observations at the high-altitude site Jungfraujoch, Switzerland, Tellus, 61B, 64-76, doi:10.1111/j.1600-0889.2010.00509.x, 2010.

Bousquet, P., Hauglustaine, D. A., Peylin, P., Carouge, C., and Ciais, P.: Two decades of $\mathrm{OH}$ variability as inferred by an inversion of atmospheric transport and chemistry of methyl chloroform, Atmos. Chem. Phys., 5, 2635-2656, doi:10.5194/acp-52635-2005, 2005.

Bousquet, P., Yver, C., Pison, I., Li, Y. S., Fortems, A., Hauglustaine, D., Szopa, S., Rayner, P. J., Novelli, P., Langenfelds, R., Steele, P., Ramonet, M., Schmidt, M., Foster, P., Morfopoulos, C., and Ciais, P.: A three-dimensional synthesis inversion of the molecular hydrogen cycle: Sources and sinks budget and implications for the soil uptake, J. Geophys. Res., 116, doi:201110.1029/2010JD014599, 2011.

Brasseur, G. P., Hauglustaine, D. A., Walters, S., Rasch, P. J., Müller, J., Granier, C., and Tie, X. X.: MOZART, a global chemical transport model for ozone and related chemical tracers 1. Model description, J. Geophys. Res., 103, 28265-28290, 1998.

Chevallier, F., Fisher, M., Peylin, P., Serrar, S., Bousquet, P., Bréon, F., Chédin, A., and Ciais, P.: Inferring $\mathrm{CO} 2$ sources and sinks from satellite observations: Method and application to TOVS data, J. Geophys. Res., 110, D24309, doi:10.1029/2005JD006390, 2005.

Chevallier, F., Bréon, F., and Rayner, P. J.: Contribution of the Orbiting Carbon Observatory to the estimation of $\mathrm{CO}_{2}$ sources and sinks: Theoretical study in a variational data assimilation framework, J. Geophys. Res., 112, 11 pp., doi:200710.1029/2006JD007375, 2007.

Conrad, R. and Seiler, W.: Decomposition of Atmospheric Hydrogen By Soil Microorganisms and Soil Enzymes., Soil Biol. Biochem., 13, 43-49, 1981.
Conrad, R. and Seiler, W.: Influence of temperature, moisture, and organic carbon on the flux of $\mathrm{H}_{2}$ and $\mathrm{CO}$ between soil and atmosphere: Field studies in subtropical regions, J. Geophys. Res., 90, 5699-5709, 1985.

Ehhalt, D. H. and Rohrer, F.: The tropospheric cycle of $\mathrm{H}_{2}$ : A critical review, Tellus, 61B, 500-535, 2009.

Engel, A. and EUROHYDROS PIs: EUROHYDROS, A European Network for Atmospheric Hydrogen observations and studies., in: EUROHYDROS Final Report, http://cordis.europa.eu/, 2009.

Erickson, D. J. and Taylor, J. A.: 3-D tropospheric CO modeling - The possible influence of the ocean, Geophys. Res. Lett., 19, 1955-1958, 1992.

Folberth, G., Hauglustaine, D. A., Ciais, P., and Lathière, J.: On the role of atmospheric chemistry in the global CO 2 budget, Geophys. Res. Lett, 32, L0881, doi:10.1029/2004GL021812, 2005.

Gerst, S. and Quay, P.: The deuterium content of atmospheric molecular hydrogen: Method and initial measurements, J. Geophys. Res., 105, 26433-26446, 2000.

Gerst, S. and Quay, P.: Deuterium component of the global molecular hydrogen cycle, J. Geophys. Res., 106, 5021-5029, 2001.

Granier, C., Hao, W. M., Brasseur, G., and Müller, J.-F.: Land use practices and biomass burning: Impact on the chemical composition of the atmosphere, in Biomass Burning and Global Change, edited by: Levine, J. S., MIT Press, Cambridge, Mass., USA, 140-148, 1996.

Grant, A., Witham, C., Simmonds, P., Manning, A., and O'Doherty, S.: A 15 year record of high-frequency, in situ measurements of hydrogen at Mace Head, Ireland, Atmos. Chem. Phys., 10, 12031214, doi:10.5194/acp-10-1203-2010, 2010.

Group, G. S. D. T.: Global Gridded Surfaces of Selected Soil Characteristics (IGBP-DIS). Data set, Oak Ridge National Laboratory Distributed Active Archive Center, Oak Ridge, Tennessee, USA, http://www.daac.ornl.gov, 2000.

Hammer, S. and Levin, I.: Seasonal variation of the molecular hydrogen uptake by soils inferred from continuous atmospheric observations in Heidelberg, southwest Germany, Tellus, 61B, 556565, 2009.

Hammer, S., Vogel, F., Kaul, M., and Levin, I.: The $\mathrm{H}_{2} / \mathrm{CO}$ ratio of emissions from combustion sources: comparison of topdown with bottom-up measurements in southwest Germany, Tellus, 61B, 547-555, 2009.

Hao, W. M., Ward, D. E., Olbu, G., and Baker, S. P.: Emissions of $\mathrm{CO}_{2}, \mathrm{CO}$, and hydrocarbons from fires in diverse African savanna ecosystems, J. Geophys. Res., 101, 23577-23584, 1996.

Hauglustaine, D. A. and Ehhalt, D. H.: A three-dimensional model of molecular hydrogen in the troposphere, J. Geophys. Res., 107, 4330, doi:10.1029/2001JD001156, 2002.

Hauglustaine, D. A., Hourdin, F., Jourdain, L., Filiberti, M. A., Walters, S., Lamarque, J. F., and Holland, E. A.: Interactive chemistry in the Laboratoire de Meteorologie Dynamique general circulation model: Description and background tropospheric chemistry evaluation, J. Geophys. Res., 109, D04314, doi:10.1029/2003JD003957, 2004.

Hough, A. M.: Development of a Two-Dimensional Global Tropospheric Model: Model Chemistry, J. Geophys. Res., 96, 7325$7362,1991$.

Hourdin, F. and Talagrand, O.: Eulerian backtracking of atmospheric tracers. I: Adjoint derivation and parametrization of subgrid-scale transport, Quarterly J. Roy. Meteorol. Soc., 132, 
567-583, 2006.

Hourdin, F., Musat, I., Bony, S., Braconnot, P., Codron, F., Dufresne, J., Fairhead, L., Filiberti, M., Friedlingstein, P., Grandpeix, J., Krinner, G., LeVan, P., Li, Z., and Lott, F.: The LMDZ4 general circulation model: climate performance and sensitivity to parametrized physics with emphasis on tropical convection, Clim. Dynam., 27, 787-813, 2006.

Jordan, A. and Steinberg, B.: Calibration of atmospheric hydrogen measurements, Atmos. Meas. Tech., 4, 509-521, doi:10.5194/amt-4-509-2011, 2011.

Kaminski, T., Rayner, P. J., Heimann, M., and Enting, I. G.: On aggregation errors in atmospheric transport inversions, J. Geophys. Res., 106, 4703-4715, doi:200110.1029/2000JD900581, 2000.

Khalil, M. A. K. and Rasmussen, R. A.: Global increase of atmospheric molecular hydrogen, Nature, 347, 743-745, 1990.

Krol, M. C., Lelieveld, J., Oram, D. E., Sturrock, G. A., Penkett, S. A., Brenninkmeijer, C. A. M., Gros, V., Williams, J., and Scheeren, H. A.: Continuing emissions of methyl chloroform from Europe, Nature, 421, 131-135, 2003.

Lallo, M., Aalto, T., Laurila, T., and Hatakka, J.: Seasonal variations in hydrogen deposition to boreal forest soil in southern Finland, Geophys. Res. Lett., 35, L04402, doi:10.1029/2007GL032357, 2008.

Lallo, M., Aalto, T., Hatakka, J., and Laurila, T.: Hydrogen soil deposition at an urban site in Finland, Atmos. Chem. Phys., 9, 8559-8571, doi:10.5194/acp-9-8559-2009, 2009.

Lamarque, J.-F., Bond, T. C., Eyring, V., Granier, C., Heil, A., Klimont, Z., Lee, D., Liousse, C., Mieville, A., Owen, B., Schultz, M. G., Shindell, D., Smith, S. J., Stehfest, E., Van Aardenne, J., Cooper, O. R., Kainuma, M., Mahowald, N., McConnell, J. R., Naik, V., Riahi, K., and van Vuuren, D. P.: Historical (1850-2000) gridded anthropogenic and biomass burning emissions of reactive gases and aerosols: methodology and application, Atmos. Chem. Phys., 10, 7017-7039, doi:10.5194/acp10-7017-2010, 2010.

Langenfelds, R. L., Francey, R. J., Pak, B. C., Steele, L. P., Lloyd, J., Trudinger, C. M., and Allison, C. E.: Interannual growth rate variations of atmospheric $\mathrm{CO} 2$ and its $\delta^{13} \mathrm{C}, \mathrm{H}_{2}, \mathrm{CH}_{4}$, and $\mathrm{CO}$ between 1992 and 1999 linked to biomass burning, Global Biogeochem. Cy., 16, 1048, doi:10.1029/2001GB001466, 2002.

Morfopoulos, C., Foster, P., Friedlingstein, P., Bousquet, P., and Prentice, I.: Modelling the soil consumption of atmospheric hydrogen at a global scale, Global Biogeochem. Cy., submitted, 2010.

Müller, J.: Geographical Distribution and Seasonal Variation of Surface Emissions and Deposition Velocities of Atmospheric Trace Gases, J. Geophys. Res., 97, 3787-3804, 1992.

Novelli, P. C., Lang, P. M., Masarie, K. A., Hurst, D. F., Myers, R., and Elkins, J. W.: Molecular hydrogen in the troposphereGlobal distribution and budget, J. Geophys. Res., 104, 3042730444, 1999.

Olivier, J. G. J., Bouwman, A. F., van der Maas, C. W. M., Berdowski, J. J. M., Veldt, C., Bloos, J. P. J., Visschedijk, A. J. H., Zandveld, P. Y. J., and Haverlag, J. L.: Description of EDGAR Version 2.0: A set of global emission inventories of greenhouse gases and ozone-depleting substances for all anthropogenic and most natural sources on a per country basis and on 1 degree $\times 1$ degree grid, Rijksinstituut voor Volksgezondheid en Milieu RIVM, 1996.
Pison, I., Bousquet, P., Chevallier, F., Szopa, S., and Hauglustaine, D.: Multi-species inversion of $\mathrm{CH} 4, \mathrm{CO}$ and $\mathrm{H} 2$ emissions from surface measurements, Atmos. Chem. Phys., 9, 5281-5297, doi:10.5194/acp-9-5281-2009, 2009.

Price, H., Jaegle, L., Rice, A., Quay, P., Novelli, P. C., and Gammon, R.: Global budget of molecular hydrogen and its deuterium content: Constraints from ground station, cruise, and aircraft observations, J. Geophys. Res., 112, D22108, doi:10.1029/2006JD008152, 2007.

Prinn, R. G., Weiss, R. F., Fraser, P. J., Simmonds, P. G., Cunnold, D. M., Alyea, F. N., O'Doherty, S., Salameh, P., Miller, B. R., Huang, J., Wang, R. H. J., Hartley, D. E., Harth, C., Steele, L. P., Sturrock, G., Midgley, P. M., and McCulloch, A.: A history of chemically and radiatively important gases in air deduced from ALE/GAGE/AGAGE, J. Geophys. Res., 105, 751-792, 2000.

Prinn, R. G., Huang, J., Weiss, R. F., Cunnold, D. M., Fraser, P. J., Simmonds, P. G., McCulloch, A., Harth, C., Reimann, S., and Salameh, P.: Evidence for variability of atmospheric hydroxyl radicals over the past quarter century, Geophys. Res. Lett., 32, L07809, doi:10.1029/2004GL022228, 2005.

Rahn, T., Eiler, J. M., Boering, K. A., Wennberg, P. O., McCarthy, M. C., Tyler, S., Schauffler, S., Donnelly, S., and Atlas, E.: Extreme deuterium enrichment in stratospheric hydrogen and the global atmospheric budget of $\mathrm{H}_{2}$, Nature, 424, 918-921, 2003.

Rhee, T. S., Brenninkmeijer, C. A. M., and Röckmann, T.: The overwhelming role of soils in the global atmospheric hydrogen cycle, Atmos. Chem. Phys., 6, 1611-1625, doi:10.5194/acp-61611-2006, 2006.

Röckmann, T., Rhee, T. S., and Engel, A.: Heavy hydrogen in the stratosphere, Atmos. Chem. Phys., 3, 2015-2023, doi:10.5194/acp-3-2015-2003, 2003.

Sanderson, M. G., Collins, W. J., Derwent, R. G., and Johnson, C. E.: Simulation of Global Hydrogen Levels Using a Lagrangian Three-Dimensional Model, J. Atmos. Chem., 46, 1528, 2003.

Schillert, A.: Parameters influencing the seasonality of $\mathrm{H} 2$ uptake in soils., State Examination Thesis, 2010.

Schmidt, U.: The latitudinal and vertical distribution of molecular hydrogen in the troposphere, J. Geophys. Res., 83, 941-946, 1978.

Schmitt, S., Hanselmann, A., Wollschläger, U., Hammer, S., and Levin, I.: Investigation of parameters controlling the soil sink of atmospheric molecular hydrogen, Tellus, 61B, 416-423, 2009.

Sitch, S., Smith, B., Prentice, I. C., Arneth, A., Bondeau, A., Cramer, W., Kaplan, J. O., Levis, S., Lucht, W., Sykes, M. T., Thonicke, K., and Venevsky, S.: Evaluation of ecosystem dynamics, plant geography and terrestrial carbon cycling in the LPJ dynamic global vegetation model, Global Change Biol., 9, 161$185,2003$.

Søvde, O. A., Gauss, M., Smyshlyaev, S. P., and Isaksen, I. S. A.: Evaluation of the chemical transport model Oslo CTM2 with focus on arctic winter ozone depletion, J. Geophys. Res., 113, D09304, doi:10.1029/2007JD009240, 2008.

Thiruchittampalam, B. and Köble, R.: European emissions map, Institut für Energiewirtschaft und Rationelle Energieanwendung(IER); University of Stuttgart, http://carboeurope.ier. uni-stuttgart.de/, 2004.

van der Werf, G. R., Randerson, J. T., Giglio, L., Collatz, G. J., Kasibhatla, P. S., and Arellano, A. F.: Interannual variability 
in global biomass burning emissions from 1997 to 2004, Atmos. Chem. Phys., 6, 3423-3441, doi:10.5194/acp-6-3423-2006, 2006.

Xiao, X., Prinn, R., Simmonds, P., Steele, L., Novelli, P., Huang, J., Langenfelds, R., O’Doherty, S., Krummel, P., and Fraser, P.: Optimal estimation of the soil uptake rate of molecular hydrogen from the Advanced Global Atmospheric Gases Experiment and other measurements, J. Geophys. Res., 112, D07303, doi:10.1029/2006JD007241, 2007.

Yonemura, S., Kawashima, S., and Tsuruta, H.: Continuous measurements of $\mathrm{CO}$ and $\mathrm{H} 2$ deposition velocities onto an andisol: uptake control by soil moisture, Tellus B - Chem. Phys. Meteorol. B, 51, 688-700, 1999.
Yonemura, S., Kawashima, S., and Tsuruta, H.: Carbon monoxide, hydrogen, and methane uptake by soils in a temperate arable field and a forest, J. Geophys. Res., 105, 14347-14362, 2000a.

Yonemura, S., Yokozawa, M., Kawashima, S., and Tsuruta, H.: Model Analysis of the Influence of Gas Diffusivity in Soil on Co and H2 Uptake, Tellus, 52B, 919-933, 2000b.

Yver, C., Schmidt, M., Bousquet, P., Zahorowski, W., and Ramonet, M.: Estimation of the molecular hydrogen soil uptake and traffic emissions at a suburban site near Paris through hydrogen, carbon monoxide, and radon-222 semicontinuous measurements, J. Geophys. Res.-Atmos., 114, D18304, doi:10.1029/2009JD012122, 2009. 